ISSN: 0213-2079 - ISSN electrónico: 2386-3889

DOI: https://doi.org/10.14201/shhmo201840263111

\title{
EL MIEDO INTERSUBJETIVO EN LA AUTOBIOGRAFÍA DE TERESA DE ÁVILA
}

\section{Inter-Subjetive Fear in Teresa de Avila's Autobiography}

\section{Elena CARRERA}

Queen Mary University of London

Correo-e: e.carrera@qmul.ac.uk

RESUMEN: En este artículo se ofrece un análisis del miedo al demonio y el miedo al infierno en la España del siglo XVI, basado en el testimonio autobiográfico de Teresa de Ávila y en influyentes guías de meditación como las de Ludolfo de Sajonia, Ignacio de Loyola y Luis de Granada. Tras hacer un repaso de los diversos enfoques metodológicos utilizados en historia de las emociones, se pone de relieve la importancia de las redes materiales, institucionales y culturales que facilitan la creación de discursos que dan forma y significado a experiencias emocionales de sujetos históricos. Además de proponerse que las emociones no radican en el sujeto individual, sino en la interacción social, las relaciones de los sujetos con los objetos, y la involucración activa de aquéllos al poner en práctica su versión de los discursos textuales y visuales que les rodean, se examinan cuatro formas de lectura de textos históricos y se demuestra cómo podemos entender emociones como el miedo al infierno o al demonio quienes no tenemos experiencia directa de esos tipos de miedo.

Palabras clave: historia de las emociones; intersubjetividad; siglo XVI; miedo al infierno; demonio.

ABSTRACT: This article offers an analysis of fear of the devil and fear of hell in sixteenth-century Spain, based on the autobiographical testimony of Teresa of Avila and on influential guides on meditation like those of Ludolph of Saxony, Ignatius of Loyola and Louis of Granada. After 
reviewing the various existing methodological approaches to the history of the emotions, the article emphasizes the importance of the material, institutional and cultural networks that enable the creation of discourses of emotion which shape and give meaning to the emotional experiences of historical subjects. In proposing that emotions do not lie in the individual, but in social interaction, in people's relationships with objects, and in their idiosyncratic ways of enacting the textual and visual discourses which surround them, the article examines four ways of reading historical texts and demonstrates how emotions such as the fear of hell or the devil can be understood by those of us who do not have direct experience of them.

Key words: history of emotions; inter-subjectivity; 16th century; fear of hell; fear of the devil.

En la autobiografía de Teresa de Ávila, conocida como El libro de la vida, encontramos una de serie de referencias a emociones que no pueden entenderse sólo como procesos biológicos, aunque estén descritas en relación con el cuerpo. Por ejemplo, Teresa menciona alguna experiencia que tiene durante la oración, que le «espeluza los cabellos», pero deja claro que la reacción biológica se da sólo en el momento inicial, y que el temor perdura, haciéndole cambiar de comportamiento: «y queda un gran temor de ofender a tan gran Dios. Éste, envuelto en grandísimo amor que se cobra de nuevo a quien vemos le tiene tan grande a un gusano tan podrido» ${ }^{1}$. Las emociones que Teresa declara sentir o haber sentido tampoco son sólo procesos mentales que orienten su comportamiento. Lo que sí tienen en común esas emociones es que sólo pueden entenderse en su contexto social.

Para Américo Castro, y para otros críticos literarios e historiadores hasta hace poco más de dos décadas, la emocionalidad que parece aflorar de los escritos de Teresa era consecuencia de la femineidad de la autora ${ }^{2}$. Esta percepción fue cuestionada de forma rotunda con la publicación en 1990 del trabajo de Alison Weber, que presenta la femineidad de los escritos de Teresa como una construcción retórica ${ }^{3}$. La pregunta que ha venido surgiendo desde entonces, y sobre todo en

1. Vida 20.7, en Teresa de Jesús, Santa: Obras completas, octava edición, preparada por E. de la Madre de Dios y O. Steggink. Madrid, 1986, p. 110. Todas las citas del Libro de la vida siguen esta edición; se incluye el número de capítulo y sección, como es habitual, para facilitar la consulta de otras ediciones.

2. Véase Carrera, Elena: «The Emotions in Sixteenth-Century Spanish Spirituality», Journal of Religious History, 31:3, 2007, pp. 235-252.

3. Weber, A.: Teresa of Avila and the Rhetoric of Femininity. Princeton, 1990. Sobre las estrategias de autorización de su escritura utilizadas por Teresa, véanse también: Slade, Carole: 
la última década, en la que se ha potenciado el estudio de la historia de la emociones, es hasta qué punto pueden verse las emociones de los textos de Teresa como «constructos» discursivos ${ }^{4}$. $\mathrm{Al}$ intentar responder a esta pregunta, nos encontramos con una cuestión metodológica clave, que intentaré dilucidar en este artículo: si esos «constructos» nos vienen dados por el texto, o si el/la historiador/a, como lector/a, debe involucrarse emocionalmente en la lectura para poder entenderlos.

La respuesta a esta pregunta dependerá del tipo de texto con el que nos enfrentemos. Por ejemplo, las alusiones al miedo que encontramos en las cartas de Teresa tienen diversas funciones, que sólo podrán entenderse si se conocen las circunstancias históricas a las que aluden, y los valores y creencias que Teresa intenta fomentar en sus destinatarios, según su posición social, edad, género y temperamento ${ }^{5}$. En cuanto a su escritura autobiográfica, cabe destacar tres acontecimientos que ella reconstruye como experiencias de «seguridad», «inseguridad» y «miedo», de los que nos ocuparemos en este trabajo: la búsqueda del martirio en 1522, la entrada en el convento en 1535, y su relación con los confesores que, en 1554-1560, creían que estaba poseída por el demonio ${ }^{6}$. Al intentar analizar esas experiencias emocionales como "constructos», partiendo del análisis discursivo del texto de Teresa, podremos diferenciar entre los tipos de lectura interactiva que podrían haber hecho sus contemporáneos, y las lecturas interactivas de lectores académicos del siglo XXI.

Por ejemplo, María Luisa Morales nos ofrece una lectura más o menos jungiana del miedo en la autobiografía de Teresa, mientras que Francisco Javier González enfatiza la evolución de la monja desde estados de confusión y terror hasta la actitud «optimista» de no hacer caso del demonio ${ }^{7}$. Otro ejemplo de lectura

Teresa of Avila. Author of a Heroic Life, Berkeley, 1995; Ahlgren, Gillian: Teresa of Avila and the Politics of Sanctity. Ithaca, 1996; Mujica, Barbara: Teresa of Avila: Lettered Woman. Nashville, 2009.

4. El enfoque constructivista, que empezó a plantearse en sociología, antropología, y una parte de la psicología en los años 80, venía inspirado en gran medida por el trabajo de Michel Foucault. Su principal premisa es que el significado que atribuimos a la experiencia es resultado de una construcción que, aunque parezca personal, forma parte de un proceso social.

5. Véase Carrera: «El miedo y la empatía en la escritura epistolar de Teresa de Jesús», en Borrego, Esther; Losada, José Manuel (Coords.): Cinco Siglos de Teresa: La proyección de la vida y los escritos de Santa Teresa de Jesús. Madrid, 2016, pp. 27-48.

6. Adopto aquí el sentido que le da Braudel al término «acontecimiento» en Braudel, Fernand: Las ambiciones de la bistoria, edición preparada por Roselyne de Ayala y Paule Braudel, trad. M. J. Furió. Barcelona, 2002, pp. 24-25: «hecho notado, señalado a nuestra atención, registrado, convertido de un modo u otro en visible para nuestra mirada [...] lo que decidirá su importancia no es el ruido que haga en su momento o el ruido que se haga en torno de él, sino las consecuencias que se deriven o no de él».

7. Morales Zaragoza, María Luisa: «Lo pavoroso en el Libro de la vida de Santa Teresa de Jesús», en Díez de Velasco Abellán, F. (Coord.): Miedo y religión. Madrid, 2002, pp. 257-264; 
interactiva, en la que se busca conocer mejor el trasfondo histórico y cultural del texto, es el reciente trabajo de Francisco García, que ofrece una interpretación ahistórica de la figura del demonio «como testigo de cargo y acusador» ${ }^{8}$. En ninguna de estas lecturas se tienen en cuenta las interpelaciones de Teresa a los lectores para quienes construyó su narración en primera instancia, ni se analiza el efecto de su interacción con los confesores que le hicieron temer al demonio más de lo debido. En este trabajo, en contrapartida, veremos cómo la noción del demonio que transpira de los textos de Teresa, y el estado emocional que ella atribuía al demonio y al miedo de sus confesores a éste, no son algo objetivo, sino más bien intersubjetivo, resultado de su interacción no sólo con los confesores, sino también con los libros que leía.

Desde la Antigüedad y hasta finales del siglo XX, se asociaba a las emociones con las mujeres, que éramos representadas como más cercanas a la naturaleza, más volubles, y menos capaces de trascender nuestros cuerpos mediante el pensamiento, el juicio y la voluntad. Esta tendencia continuó dominando la historiografía sobre la Edad Moderna, a pesar de la publicación, durante el siglo XX, de una serie de trabajos seminales sobre el miedo en la historia, como los de Édouard Forestie, George Lefebvre o Jean Delumeau en Francia, y Vito Fumagalli y Piero Camporesi en Italia9. Mientras que, según los estudios de Forestie, Lebebvre y Delumeau, el miedo, el pánico y el terror colectivos parecían afectar de igual modo a hombres y a mujeres (si bien más a unos grupos sociales que a otros), otras emociones

González Candela, Francisco Javier: «El contraste místico del bien y el mal: la presencia del demonio en la Vida de santa Teresa de Jesús», en Mata Induráin, Carlos; Zúñiga Lacruz, Ana (Coords.): «Venia docendi». Actas del IV Congreso Internacional Jóvenes Investigadores Siglo de Oro (JISO 2014). Pamplona, 2015, pp. 85-94.

8. García Rubio, Francisco: «La función retórico-jurídica del demonio en el Libro de la vida de Teresa de Jesús», eHumanista, 17, 2011, pp. 185-204 (185).

9. Forestié, Edouard: La Grande Peur. Montauban, 1911; Lefebvre, Georges: La Grande peur de 1789. París, 1932; Delumeau, Jean: El miedo en Occidente (siglos XIV-XVIII): una ciudad sitiada, trad. M. Armiño. Madrid, 1989 [Orig. 1978]; Delumeau: Le Péché et la peur: La culpabilisation en Occident (XIIIe-XVIIIe siècles). París, 1983; Delumeau: Rassurer et Protéger. Le sentiment de sécurité dans l'Occident d'autrefois. París, Fayart, 1989; Fumagalli, Vito: Landscapes of Fear: Perceptions of Nature and the City in the Middle Ages, trad. S. Mitchell. Stanford/Londres, 1994 [orig. 1976]; Camporesi, Piero: The Fear of Hell: Images of Damnation and Salvation in Early Modern Europe, trad. L. Byatt. Oxford, 1990 [orig. 1987]. Véanse también: MacDonald, Michael: Mystical Bedlam: Madness, Anxiety, and Healing in Seventeenth-Century England. Cambridge, 1981; MacDonald: "The Fearefull Estate of Francis Spira: Narrative, Identity, and Emotion in Early Modern England», Journal of British Studies, 31:1, 1992, pp. 32-61; Naphy, William G.; Roberts, Penny: Fear in Early Modern Society. Manchester, 1997. Para el siglo XX, véanse: Dunant, Sarah; Porter, Roy: The Age of Anxiety. Londres, 1996; Bourke, Joanna: «Fear and Anxiety: Writing about Emotion in Modern History», History Workshop Journal, 55:1, 2003, pp. 111-133. 
pre-modernas, como la ira, parecían haber sido expresadas con un mayor grado de codificación, según las fuentes históricas analizadas en la colección de ensayos coordinada por Barbara Rosenwein a finales de siglo ${ }^{10}$. Ya entonces se empezaba a vislumbrar una amplia gama de formas históricas de expresión de sentimientos, dependiendo de la situación, el momento histórico y los valores culturales que prevalecieran en esos contextos geográficos y sociales. Rosenwein desarrollaría esta idea en un influyente trabajo en el que propuso la noción de «comunidades emocionales», aglutinadas en torno a emociones nombradas explícitamente en tratados morales, epitafios funerarios y otros documentos de la Alta Edad Media ${ }^{11}$. El enfoque de Rosenwein, en cierta medida determinado por las escasas fuentes de las que disponemos para ese periodo, no permitía concebir que un individuo perteneciera a más de una «comunidad emocional», como parece haber sido el caso de individuos de épocas posteriores, de los que tenemos testimonios en primera y en tercera persona, como Teresa de Ávila. Además, el concepto de «comunidad emocional» ha venido siendo utilizado en la reconstrucción de regímenes emocionales dominantes a partir de fuentes prescriptivas como los tratados morales, y no ha ayudado a resaltar la importancia de las transgresiones y las experiencias conflictivas de las que dan cuenta otro tipo de fuentes, como las judiciales ${ }^{12}$. Tampoco ha permitido tener en cuenta la complejidad de los contextos sociales en los que se inscriben las interacciones emocionales, que han puesto de relieve recientes trabajos como los de Lyndal Roper, Carol Lansing, Fay Bound Alberti, Susan Karant-Nunn o Erin Sullivan, y los coordinados por Penelope Gouk y Helen Hills, por Fay Bound Alberti, por Victoria Kahn, Neil Saccamano y Daniela Coli, por María Tausiet y James Amelang, por Damien Boquet y Piroska Nagy, por Pilar Gonzalbo Aizpuru, Ann Staples y Valentina Torres Septién, por Elena Carrera, por Jonas Liliequist, por Carolina Rodríguez-López, por Mónica Bolufer, por José Javier Díaz Freire, por Juan Pro, por Jennifer Spinks y Charles

10. Rosenwein, Barbara H. (Coord.): Anger's Past: The Social Uses of an Emotion in the Middle Ages. Ithaca, 1998.

11. Rosenwein: Emotional Communities in the Early Middle Ages. Ithaca, 2006. Véanse también Rosenwein: «Problems and Methods in the History of Emotions», Passions in Context: Journal of the History and Philosophy of the Emotions, 1, 2010, pp. 1-32; Plamper, Jan: "The History of the Emotions: An Interview with William Reddy, Barbara Rosenwein, and Peter Stearns», History and Theory, 49:2, 2010, pp. 237-265.

12. Entre los trabajos que muestran la tensión entre transgresión, negociación y adhesión a los regímenes emocionales dominantes véase Pascua Sánchez, María José de la: Mujeres solas: bistorias de amor y de abandono en el mundo hispánico. Málaga, 1998; «Regulación de los afectos y la cultura del amor en la sociedad hispana de la época Moderna», en Iglesias Rodríguez, Juan José; Pérez García, Rafael M.; Fernández Chaves, Manuel Francisco (Coords.): Comercio y cultura en la Edad Moderna. Actas de la XIII Reunión Científica de la Fundación Española de Historia Moderna. Sevilla, 2015. 
Zika, por Claudia Jarzebowski y Thomas Safley, por Erika Kuijpers y Cornelis van der Haven, por Susan Broomhall, o por Michael Braddick y Joanna Innes ${ }^{13}$.

William Reddy, otro de los historiadores que han creado escuela a la hora de examinar la función de las emociones en la historia, proponía que «la unidad de una comunidad depende en parte de su capacidad de proporcionar normas coherentes sobre lo que debe sentirse», si bien se centraba en contextos político-culturales dominados por un tipo de sentimentalidad que parecía borrar las diferencias de género $^{14}$. En contrapartida, la antropóloga Catherine Lutz, cuyo enfoque constructivista ha tenido un eco considerable entre los historiadores de las emociones,

13. Roper, Lyndal: Witch Craze: Terror and Fantasy in Baroque Germany. New Haven, 2004; Lansing, Carol: Passion and Order: Restraint of Grief in the Medieval Italian Communes. Ithaca, 2008; Bound Alberti, Fay: Matters of the Heart: History, Medicine, and Emotion. Nueva York/Oxford, 2010; Karant-Nunn, Susan: The Reformation of Feeling: Shaping the Religious Emotions in Early Modern Germany. Nueva York/Oxford, 2010; Sullivan, Erin: Beyond Melancholy: Sadness and Selfhood in Renaissance England. Oxford, 2016; Gouk, Penelope; Hills, Helen (Coords.): Representing Emotions: New Connections in the Histories of Art, Music and Medicine, Aldershot, 2005; Bound Alberti (Coord.): Medicine, Emotion and Disease, 1700-1950. Basingstoke, 2006; Kahn, Victoria; Saccamano, Neil; Coli, Daniela: Politics and the Passions, 1500-1850. Princeton, 2006; Tausiet, María; Amelang, James S. (Coords.): Accidentes del alma: las emociones en la Edad Moderna. Madrid, 2009; Nagy, Piroska ; Boquet, Damien (Coords.): Le Sujet des émotions au moyen âge. París, 2009; Boquet ; Nagy (Coords.): Politiques des émotions au Moyen Âge. Florencia, 2010; Boquet; Nagy (Coords.): Sensible Moyen Âge. París, 2015; Rosas Lauro, Claudia (Coord.): El miedo en Perú: siglos XVI al XX. Lima, 2005; Gonzalbo Aizpuru, Pilar; Staples, Anne; Torres Septién, Valentina (Coords.): Una historia de los usos del miedo, México, D.F., 2009; Carrera (Coord.): Emotions and Health, 1200-1700. Leiden/Boston, 2013; Liliequist, Jonas: A History of Emotions, 1200-1800. Londres, 2012; Jarzebowski, Claudia; Safley, Thomas M. (Coords.): Childhood and Emotion across Cultures 1450-1800. Londres, 2014; Rodríguez-López, Carolina (Coord.): «Historia de las emociones», monográfico en Cuadernos de Historia Contemporánea, 36, 2014; Bolufer Peruga, Mónica (coord.): «Del uso de las pasiones: la civilización y sus sombras», monográfico en Historia Social, 81, 2015; Díaz Freire, José Javier (Coord.): «Emociones e historia», monográfico en Ayer, 98, 2015; Bolufer Peruga (Coord.): Del uso de las pasiones: la civilización y sus sombras. Historia Social, 81, 2015; Pro, Juan: Dossier «Historia de las emociones», en Rubrica contemporanea, 4:7, 2015; Spinks, Jennifer; Zika, Charles (Coords.): Disaster, Death and the Emotions in the Shadow of the Apocalypse, 1400-1700. Basingstoke, 2016; Kuijpers, Erika; van der Haven, Cornelis (Coords.): Battlefield Emotions 1500-1850: Practices, Experience, Imagination, Basingstoke, 2016; Broomhall, Susan (Coord.): Early Modern Emotions: An Introduction. Londres/Nueva York, 2017; Braddick, Michael J. y Innes, Joanna (Coords.): Suffering and Happiness in Early Modern England. Oxford, 2017.

14. Reddy, William M.: The Navigation of Feeling: A Framework for the History of Emotions. Cambridge, 2001, p. 61: «the unity of a community depends in part on its ability to provide a coherent set of prescriptions about emotions». Véase también su reciente trabajo: The Making of Romantic Love. Chicago, 2012. Par una valoración de las aportaciones de Reddy a la historia de las emociones, véase Moscoso, Javier: «La historia de las emociones: ¿de qué es historia?», Vinculos de Historia, 4, 2015, pp. 15-27 (20-24). 
sugería que para estudiar las emociones desde un punto de vista feminista hay que «tener en cuenta las redes materiales, institucionales y culturales de poder mediante las que operan los discursos emocionales» ${ }^{15}$. Aplicando la perspectiva del constructivismo social a la antropología histórica y cultural, Monique Scheer ha puesto el énfasis en la dimensión corpórea de la expresión emocional: «el efecto de los lazos que nos atan a otras personas, así como a las convenciones sociales, a los valores y al lenguaje» ${ }^{16}$.

Los planteamientos inspirados por la antropología y el análisis del discurso nos ayudan a cuestionar la concepción de las emociones como experiencias subjetivas, situadas dentro del individuo, y a prestar más atención a los marcos sociales en los que éstas se generan, se reproducen y se distribuyen. Un ejemplo de estos planteamientos es el análisis que nos ofrece Sara Ahmed de las emociones como "prácticas sociales», que se construyen y se entienden a través de un imaginario colectivo, del que formamos parte a través de nuestra interacción social ${ }^{17}$. Jo Labanyi, apoyándose en el enfoque de Ahmed, planteaba que a la hora de estudiar las emociones, los afectos, y la materialidad corporal y social en la que se inscriben, deberíamos entender la subjetividad en términos relacionales, de interacción. En lugar de ver la subjetividad como algo basado en ideas y sentimientos que son propiedad del «yo», deberíamos entenderla como producto de la interacción entre el «yo» y el mundo, un mundo en el que se integran sujetos y objetos:

15. Lutz, Caterine A.: «Feminist Emotions», en Mageo, Jeannette Marie (Coord.): Power and the Self. Cambridge, 2002, pp. 194-215 (197): «attention to the material, institutional and cultural capillaries of power through which discourses of emotion operate». Entre los estudios más recientes sobre emociones y género en la historia cabe destacar: Pascua Sánchez, María José de la; García-Doncel Hernández, María del Rosario; Espigado Tocino, Gloria (Coords.): Mujer y deseo. Representaciones y prácticas de vida. Cádiz, 2004; Shields, Stephanie A.: Speaking from the Heart: Gender and the Social Meaning of Emotion. Nueva York, 2000; Shields: «Passionate Men, Emotional Women: Psychology Constructs Gender Difference in the 19th Century", History of Psychology, 10, 2007, pp. 92-110; Barclay, Katie: Love, Intimacy and Power: Marriage and Patriarchy in Scotland, 1650-1850. Manchester, 2011; Broomhall (Coord.): Authority, Gender and Emotions in Late Medieval and Early Modern England. Houndmills, 2015; Broomhall (Coord.): Gender and Emotions in Medieval an Early Modern Europe: Destroying Order, Structuring Disorder. Farnham, 2015; Foka, Anna; Liliequist, Jonas: Laughter, Humor, and the (Un)Making of Gender: Historical and Cultural Perspectives. Nueva York, 2015; Candau Chacón, María Luisa (Coord.): Las mujeres y las emociones en Europa y América: siglos XVII-XIX. Santander, 2016.

16. Scheer, Monique: «Are Emotions a Kind of Practice (and is That What Makes Them Have a History)? A Bourdieuian Approach to Understanding Emotion», History and Theory, 51:2, 2012, pp. 193-220 (207): «embodied effect of our ties to other people, as well as to social conventions, to values, to language».

17. Ahmed, Sara: The Cultural Politics of Emotion. Nueva York, 2004 [La politica cultural de las emociones, trad. C. Olivares. México, D. F., 2015]. 
No sugiero que abandonemos el estudio de la subjetividad, pero propondría un concepto de subjetividad basado en la relacionalidad con otras personas y con los objetos. Ello supondría prestar atención tanto a los sentimientos como a las ideas, y considerar los sentimientos no como propiedad del «yo», sino como producto de la interacción entre el yo y el mundo ${ }^{18}$.

Quizá cabría añadir que, como veremos en relación con el testimonio de Teresa, la subjetividad también se construye en las relaciones de los sujetos corporeizados con los discursos (textuales y visuales) que éstos leen, escuchan y ven.

La idea que Ahmed y Labanyi, entre otros, han puesto de relieve, de que los sentimientos no residen ni en los sujetos ni en los objetos, sino que se construyen en las interacciones entre sujetos, entendidos como entes corporeizados, y entre éstos y los objetos, nos lleva a la primera cuestión metodológica que planteábamos en la introducción: hasta qué punto la comprensión de emociones que aparecen en textos históricos depende de la involucración personal de quienes leen los textos. Ahmed hace un uso ejemplar del pluralismo metodológico al invitarnos a ver las emociones no en los materiales que analizamos, sino en nuestra interacción con esos materiales. Desde la perspectiva que propone, no se trataría tanto de identificar cómo interpretamos los materiales, según emociones que nos dominan como lectores, sino de analizar lo que «hacen», es decir, qué efectos generan sobre nosotros. La pregunta que surge aquí es si el efecto que tienen los materiales sobre quienes los leen es unidireccional; es decir, si sólo va del texto a quienes lo leemos o escuchamos.

A la hora de analizar lo que «hacen» los textos, el impacto que tienen sobre el lector, cabe distinguir al menos cuatro tipos de lectores/as: 1) aquéllos/ as para quienes se escribe el texto; 2) los/as lectores/as que no comparten el contexto socio-cultural del texto; 3 ) los/as que buscan pistas contextuales en el texto (por ejemplo, los/as proponentes del Nuevo Historicismo); 4) los/as que se adentran emocionalmente en el texto, intentando respetar su alteridad. Si traemos la autobiografía de Teresa al siglo XXI, la mayoría de los lectores sería del segundo tipo.

El primer tipo de lector/a, en el de caso de la autobiografía de Teresa, sería en primera instancia, el teólogo dominico García de Toledo, a quien ella envía su extenso relato, deseando que les aproveche la lectura a él y a los confesores a los

18. Labany, Jo: «Doing Things: Emotion, Affect, and Materiality», Journal of Spanish Cultural Studies, 11: 3-4, 2010, pp. 223-233 (223): «I do not propose that we abandon the study of subjectivity, but would like to argue for a concept of subjectivity that is based on relationality with others and with things. That means paying attention to feelings as well as ideas, and viewing feelings, not as properties of the self, but as produced through the interaction between self and world». 
que ella pide que se lo envíe ${ }^{19}$. A ese dominico Teresa le interpela directamente, diciéndole que no se sorprenda de que una mujer mayor y sin estudios universitarios tenga más conocimiento directo de Dios que un doctor en teología, y recordándole que la clave para no engañarse es la modestia:

No se espante ni le parezcan cosas imposibles -todo es posible a el Señor-, sino procure esforzar la fe y humillarse de que hace el Señor en esta ciencia a una vejecita más sabia por ventura que a él, aunque sea muy letrado, y con esta humildad aprovechará más a las almas y a sí que por hacerse contemplativo sin serlo. Porque torno a decir que si no tiene espiriencia, si no tiene muy mucha humildad en entender que no lo entiende y que no por eso es imposible, que ganará poco y dará a ganar menos a quien trata. No haya miedo, si tiene humildad, primita [sic] el Señor que se engañe el uno ni el otro ${ }^{20}$.

Como vemos, el objetivo explícito de la autobiografía es que el dominico deje de confiar en la autoridad y poder que le da su posición como teólogo y como miembro de una ilustre familia aristocrática, y que él y otros teólogos aprendan a juzgar sin miedo a quienes tienen más experiencia espiritual que ellos, aunque sean mujeres.

Una muestra clara de la bidireccionalidad de la interacción entre el texto y el lector es que, de vez en cuando, Teresa interrumpe su narración con alusiones al momento de la escritura, y al efecto que le produce el anticipar cómo va a recibir el escrito el ilustre dominico, a quien hace presente con la típica fórmula de cortesía, «vuestra merced»: «Otras cosas muchas quisiera decir, sino que he miedo me dirá vuestra merced que para qué me meto en esto». ${ }^{21}$ Por lo que podemos observar, Teresa no sólo considera el impacto que puedan tener sus palabras en su destinatario, sino también el efecto que tiene ese destinatario, o más bien las expectativas que ella le atribuye, a la hora de seleccionar qué incluir en el relato, y qué forma darle.

19. Según se lee en la carta-epílogo con la que remite a García de Toledo la primera versión de la Vida, Teresa tenía la intención de que se hiciera llegar el libro al maestro espiritual Juan de Ávila: «Suplico a vuestra merced lo enmiende y mande trasladar -si se ha de llevar al padre maestro Ávila-, porque podría ser conocer alguien la letra. Yo deseo harto se dé orden en cómo lo vea, pues con ese intento lo comencé a escrivir», Vida, p. 229. Los otros confesores que ella espera que lean su relato incluyen el dominico Domingo Báñez y los jesuitas Baltasar Álvarez y Gaspar de Salazar. Sobre Teresa y los jesuitas, y sobre el papel de éstos en la reforma teresiana, véanse Dalmases, Cándido de: «Santa Teresa y los Jesuitas. Precisando fechas y datos», Archivum Historicum Societatis Jesu, 35, 1966, pp. 347-378; Rodríguez-San Pedro Bezares, Luis. E.: «La dualidad de Teresa de Jesús y el proyecto de «Jesuitas Descalzos»», Hispania Sacra, 68, 2016, pp. 299-315.

20. Vida 34.12 , pp. 187-188.

21. Vida 27.18, p. 148. 
Un ejemplo del tercer tipo de lectura de la autobiografía de Teresa son los estudios que, teniendo en cuenta el contexto histórico y cultural en el que se escribió, cuestionan y desarrollan los planteamientos de Foucault sobre la subjetividad como producto de relaciones de poder y de prácticas socializadoras ${ }^{22}$. Como puede comprobarse, los enfoques foucauldianos han tendido a centrarse en las redes de control del conocimiento como algo que dependía sólo de la posición social de los sujetos, y no han tenido en cuenta prácticas de lectura tradicionales, como las del contexto devocional en el que se inscribe Teresa de Ávila, en las que lo que importaba no era descifrar conceptos intelectuales abstractos sino saber involucrarse emocionalmente en lo que se leía ${ }^{23}$.

La lectura que se ofrece en este trabajo correspondería al cuarto tipo de lector/a: quienes permiten que la lectura amplíe sus puntos de vista, e intentan entender el posicionamiento emocional e ideológico desde el que se ha escrito el texto, respetando su alteridad ${ }^{24}$. Un ejemplo de la alteridad u otredad de la autobiografía de Teresa de Ávila puede ser los puntos de vista que nos ofrece sobre el miedo al infierno o el miedo al demonio, que quizá podamos llegar a entender en su contexto histórico, sin haber experimentado nada que se les parezca ${ }^{25}$. La

22. Carrera: Teresa of Avila's Autobiography: Authority, Power and the Self in Mid-SixteenthCentury Spain. Oxford, 2005; Pascua Sánchez: «Teresa de Jesús, cultura del yo e historia de las mujeres», en Callado Estela, Emilio (Coord.): Viviendo sin vivir en mí: Estudios en torno a Teresa de Jesús en el V Centenario de su nacimiento. Madrid, 2016, pp. 43-72. La evolución de las perspectivas de Foucault sobre la subjetivación, como producto de fuerzas externas al sujeto o como consecuencia de prácticas transformativas en las que se involucra el sujeto, puede verse en Foucault, Michel: Vigilar y castigar. México, D.F., 1990 [orig. 1975]; Foucault: «El Sujeto y el Poder», en Dreyfus, Hubert L.; Rabinow, Paul (Eds.): Más allá del Estructuralismo y la Hermenéntica, trad. C. de Iturbe. México, DF, 1988 [orig. 1982]; Foucault: La hermenéutica del sujeto. Curso en el Collège de France, 1981-1982. Buenos Aires, 2009 [orig. 2001]; Foucault: Tecnologías del yo y otros textos afines, trad. M. Allendesalazar, Barcelona, 1990 [orig. 1988]; Foucault: «La ética del cuidado de si como práctica de la libertad», trad. D. Fonti, en Nombres. Revista de Filosofía, 10:15, 2000, pp. 257-280 [entrevista 1984; publicación orig. 1994]. Véase también: Val Valdivieso, María Isabel del; Gallego Franco, Henar (Coords.): Las huellas de Foucault en la historiografía: poderes, cuerpos y deseos. Barcelona, 2013.

23. Es la técnica de lectura que di en llamar «hermenéutica afectiva»; véase Carrera: «Writing Rearguard Action, Fighting Ideological Selves: Teresa of Avila's Reinterpretation of Gender Stereotypes in Camino de perfección", Bulletin of Hispanic Studies, 79:3, 2002, pp. 299-308.

24. Entre los mejores exponentes de este tipo de lectura están los trabajos de Teófanes Egido. Véase, por ejemplo, Egido, Teófanes: «Santa Teresa y sus cartas, historia de los sentimientos», Hispania Sacra, 67, 2015, pp. 401-428. En esa línea se inscriben también Carrera: «El miedo y la empatía»; IBID: «From Fear to Courage: The Testimonies of Teresa of Avila and her Early Hagiographers», en O’Reilly, Terence; Thompson, Colin; Twomey, Lesley (Coords.): Saint Teresa of Avila: Her Writings and Life. Oxford, 2018, pp. 150-166.

25. Para entender esos miedos en sus contextos socio-culturales, véanse Moncy, Agnes: «Santa Teresa y sus demonios», Papeles de Son Armadans, 36:107, 1965, pp. 149-166; Llamas 
consideración de este cuarto tipo de lector/a nos lleva a preguntarnos dónde se sitúa la interactividad cuando leemos un texto.

Para responder, podríamos empezar por tomar la autobiografía de Teresa, El libro de la vida, como narración. Para entender cualquier narración autobiográfica, no basta con verla como documento histórico que nos proporcione una valiosa evidencia sobre cómo se vivían las emociones en el pasado. No basta el método que empezaron a proponer los formalistas en los años 20 y los estructuralistas en los años 60, de acercarse al texto como un todo cerrado, que contenía todas las pistas necesarias para entenderlo. Y tampoco bastan los enfoques, de origen decimonónico, que buscaban entender un texto identificando sus fuentes textuales. El enfoque que parece más apropiado en el contexto académico interdisciplinar de este momento tiene que ver con lo que ha dado en llamarse «enaction», que parte de la premisa de que las narraciones no pueden entenderse sin involucrarse en ellas. Este enfoque parece tener algo que ver con la «teoría de la recepción» que empezó a desarrollar Stanley Fish en 1970 (la idea de que el texto no existe independientemente del sujeto, sino que es el sujeto, o más bien la comunidad de sujetos la que construye el texto al interpretarlo), pero va más allá. También supone una revisión del enfoque unidireccional de los postestructuralistas, que a partir de los años 70 empezaron a llamar nuestra atención sobre el hecho de que el sujeto que escribe se construye a sí mismo al escribir. Frente a la visión tradicional de que quien habla o escribe está usando la lengua como mero instrumento de comunicación, los postestructuralistas sugerían que es la lengua la que construye a quien habla o escribe.

Más allá de los enfoques unidireccionales de la teoría de la recepción y del postestructuralismo, en la segunda década de este milenio se nos anima a entender los procesos cognitivos como algo interactivo, y por tanto bidirecciona ${ }^{26}$. Por

Martinez, Enrique: «Demonismo y hechicería en El libro de la Vida», en Barrientos, A. (Coord.): Introducción a la lectura de Santa Teresa. Madrid, 2002, pp. 210-240; Lisón Tolosana, Carmelo: Demonios y exorcismos de los Siglos de Oro. La España mental I. Madrid, 1990. Roig, Rosendo: «De la visión del infierno a la visión del primer Carmelo (comentario estilístico del capítulo XXXII del «Libro de la vida» de Santa Teresa)», Letras de Deusto, 12:24, 1982, pp. 59-76; Duviols, Jean Paul; Moliné-Bertrand, Annie (Coords.): Enfers et damnations dans le monde hispanique et hispano-américain. París, 1996; Tausiet; Amelang (Coords.): El Diablo en la Edad Moderna. Madrid, 2004; Pino Díaz, Fermín del (Coord.): Demonio, religión y sociedad entre España y América. Madrid, 2002; Delumeau: «Le démon, l'enfer et les peurs de la Renaissance», Le Monde des Religions, Marzo-abril 2005, pp. 38-39; Ward, Laura; Steeds, Will: Demonios. Visión del diablo en el arte, trad. A. Lino Gonzalvo. Madrid, 2007.

26. Por ejemplo, partiendo de la hipótesis del «cerebro interactivo», Ezequiel Di Paolo y Hanne De Jaegher han propuesto un enfoque metodológico interdisciplinar (combinando la neurociencia, la fenomenología y la filosofía de la mente) para explicar la dimensión social de la experiencia. Véase Di Paolo, Ezequiel; De Jaegher, Hanne: «The Interactive Brain Hypothesis», Frontiers in Human Neuroscience, 6:163, 2012, pp. 1-16. 
ejemplo, Yanna Popova propone que, en lugar de centrarnos en el texto escrito o discurso oral como objeto de estudio, o en el lector o escuchador como agente sin el que ese texto no existiría, entendamos la narración como un proceso intersubjetivo de creación de significado entre dos agentes: quien narra la historia (el narrador; no el autor) y quien la lee o la escucha ${ }^{27}$. Es un proceso de colaboración, o co-construcción de la historia narrada, en la que participa el lector o escuchador junto con el narrador o narrador ${ }^{28}$. Es una experiencia interactiva que transciende barreras culturales, temporales y físicas, y amplía su punto de vista para incluir no sólo el «aquí y ahora» de la lectura o escucha, sino también el «allí y entonces» del momento en que se narra la historia.

Podemos empezar a responder a la pregunta de hasta qué punto puede verse la lectura como un proceso intersubjetivo situando la interactividad en tres espacios y momentos del siglo XVI: en 1522 (cuando Teresa lee vidas de santos), en 1562 (cuando escribe la primera versión de su autobiografía) y en 1590 (cuando el jesuita Francisco de Ribera escribe una hagiografía basada en el texto de Teresa). Si además queremos entender esas lecturas interactivas y nuestra propia lectura desde el contexto cultural en el que nos inscribimos como historiadores/as, nos encontramos con la perspectiva interdisciplinar denominada «enaction», que explica que el lector puede dar vida a lo que lee, mediante procesos de simulación y empatía que la «neurociencia social» ha situado en el «cerebro social». ${ }^{29}$ Ahora bien, las teorías neurocientíficas de la empatía tienden a centrase en un modelo reductivo, basado en la imitación automática y pre-verbal, que suele localizarse en las llamadas neuronas espejo, y no explican la función clave que tienen las creencias en el tipo más sofisticado de imitación en la que interviene el lenguaje, y que supone una involucración tanto emocional como ideológica, como se ve en el ejemplo de Teresa, la niña de siete años que en 1522 quiere morir mártir.

27. Popova, Yanna B.: Stories, Meaning, and Experience: Narrativity and Enaction. Nueva York, 2015.

28. Al hablar de narración, el enfoque intersubjetivo no se limita a las historias contadas con palabras, sino también a las historias que cuentan las imágenes y las formas musicales. Son narraciones tanto los libros de historia, o lo que se cuenta ante un tribunal de justicia, como lo que se narra en novelas o películas. Quien lee o escucha la historia está representando (o dando vida a, «enacting») el punto de vista de quien la narra, o el punto de vista de quien vive los hechos narrados.

29. Véase por ejemplo el modelo basado en la antropología y la neurociencia mediante el que se intenta explicar el aprendizaje cultural imitativo en Losin, Elizabeth A. Reynolds; Dapretto, Mirella; Iacoboni, Marco: «Culture in the Mind's Eye: How Anthropology and Neuroscience Can Inform a Model of the Neural Substrate for Cultural Imitative Learning», Progress in Brain Research, 178, 2009, pp. 175-190; Hoffman, Martin L.: «Empathy and prosocial behavior», en Feldman Barrett, Lisa; Lewis, Michael; Haviland-Jones, Jeannette M. (Coords.): Handbook of Emotions, tercera edición. Nueva York/Londres, 2010, pp. 440-455 (441). 


\section{LECTURA INTERACTIVA EN 1522: LA SUBJETIVACIÓN DE TERESA A LOS SIETE AÑOS}

En el primer capítulo de su autobiografía, Teresa nos cuenta que ella y su hermano Rodrigo solían leer vidas de santos:

Pues mis hermanos ninguna cosa me desayudaban a servir a Dios. Tenía uno casi de mi edad, (juntávamonos entrambos a leer vidas de Santos), que era el que yo más quería, aunque a todos tenía gran amor y ellos a mí. Como veía los martirios que por Dios las santas pasavan, parecíame compravan muy barato el ir a gozar de Dios y deseaba yo mucho morir ansí, no por amor que yo entendiese tenerle, sino por gozar tan en breve de los grandes bienes que leía haver en el cielo, y juntávame con este mi hermano a tratar qué medio habría para esto. Concertávamos irnos a tierra de moros, pidiendo por amor de Dios, para que allá nos descabezasen; y paréceme que nos dava el Señor ánimo en tan tierna edad, si viéramos algún medio, sino que el tener padres nos parecía el mayor embarazo. Espantávanos mucho el decir que pena y gloria era para siempre, en lo que leíamos. Acaecíanos estar muchos ratos tratando de esto y gustávamos de decir muchas veces: ipara siempre, siempre, siempre! ${ }^{30}$

Un lector de nuestro siglo que no esté familiarizado con el uso del español en el siglo XVI entendería la idea de espantar como una experiencia relacionada con el miedo. Sin embargo, si nos posicionamos en el punto de mira del cuarto tipo de lector/a, veremos que el término «espantar» tenía un significado más amplio en el contexto de Teresa, relacionado con la admiración y la estupefacción. Esta acepción del término tiene más sentido, dada su afirmación de que de niña le «espantaba» no sólo la idea del sufrimiento eterno, sino también la del gozo eterno. Al fin y al cabo, era la idea del gozo eterno la que, según se contaba en las vidas de santos, ayudó a niñas y a mujeres jóvenes a enfrentarse al martirio con serenidad. Esa imagen de serenidad se construía, reproducía y promovía a través de la iconografía religiosa ${ }^{31}$.

La valentía, o quizá simpleza, que según el testimonio de Teresa la llevaron a querer que la descabezasen los moros a los 7 años estaba marcada por sentimientos como la esperanza y la confianza, que se habían ido forjando mediante sus lecturas de vidas de santos, como el Flos sanctorum ${ }^{32}$. Al parecer, la lectura de estos libros

30. Vida 1.5 , p. 35 .

31. Por ejemplo, el retablo sobre la flagelación de Santa Marina pintado por Pedro de Mayorga en Valladolid en 1500, que puede verse en el Museo de Bellas Artes de Asturias (Colección Pedro Masaveu), capta la imagen de serenidad de la niña mártir al ser flagelada, justo antes de ser decapitada por negarse a renunciar a ser cristiana.

32. Este era el título por el que se conocían las diversas versiones castellanas de la Legenda aurea de Jacobo de la Vorágine, que tuvieron un gran éxito editorial en el siglo XVI. Se cree que Teresa leyó la versión castellana compuesta por Pedro de la Vega en 1513 y publicada al 
no sólo infundía miedo al sufrimiento eterno del infierno (que le esperaría tras la muerte si esta le pillaba desprevenida), sino que también alimentaba los deseos de los lectores de alcanzar cuanto antes el gozo eterno; estos deseos servían a su vez para contrarrestar el miedo a la muerte. Puede decirse que las vidas de santos tenían la doble función de incitar miedo y dar seguridad: quienes temieran la muerte, o la condena eterna, sólo tenían que seguir el ejemplo de los santos, o rezarles a esos santos para erradicar el miedo y sentirse seguros.

La cantidad y calidad de la información que proporcionaban las vidas de santos y la estructura de éstas iban supeditadas al objetivo de promover un modelo de heroicidad basado en la esperanza en el más allá. En este sentido, las vidas de las vírgenes mártires sólo resultarán comprensibles para aquellos lectores que estén familiarizados con las ideas cristianas sobre los tres posibles destinos alcanzables tras la muerte: la felicidad absoluta e infinita del cielo, el eterno e inconmensurable sufrimiento del infierno, o la espera incierta del purgatorio. Para los niños de familias cristianas (o cristianizadas, como la de Teresa, cuyo padre era de origen judío), las vidas y las injustas muertes de las santas mártires resultaban mucho más atractivas que la mayoría de las historias que solían contarse en los sermones, y en libros como el Vita Christi cartujano, sobre el lento sufrimiento de Cristo y de su madre ${ }^{33}$. Las imágenes de gozo sereno de mártires como Santa Marina también resultaban mucho más interesantes y relevantes que las descripciones de las penas eternas del infierno, con las que los predicadores solían intentar asustar a sus feligreses. No es de sorprender que Teresa quisiera dejar constancia de su temprana involucración personal en un proceso de lectura que no sólo la interpelaba como sujeto pasivo, sino que le hacía sentir miedo, admiración, esperanza y confianza, y le inspirada a actuar de forma heroica, siguiendo uno de los escasos modelos de santidad que en aquel momento parecían estar al alcance de un lector con cuerpo de niña: el martirio.

A la mayoría de los lectores del siglo XXI, la información que da Teresa sobre sus aspiraciones a ser mártir les parecerá insuficiente, y posiblemente irrelevante. Sin embargo, si tomamos el texto de Teresa como documento histórico, podemos situarlo en el campo de acción de los predicadores y libros devocionales de la primera mitad del siglo XVI. Si bien no sabemos cómo sentían miedo al infierno los cristianos de esa época que lo sintieran, sabemos que si iban a la iglesia, o leían o escuchaban alguno de los libros devocionales más vendidos en ese momento, como el Flos sanctorum en traducción vernácula, se verían expuestos a ese miedo interactivo.

menos siete veces entre 1520 y 1569 .

33. El Vita Christi de Ludolfo de Sajonia había sido traducido al castellano por Fray Ambrosio de Montesino en 1502-1503. El Vita Christi y el Flos sanctorum estaban entre los pocos libros que recomendaría Teresa para los conventos que empezó a fundar casi 50 años después; véase Constituciones 1.13 en Teresa de Jesús: Obras, pp. 827-840 (821). 


\section{SUBJETIVACIÓN DE TERESA COMO SUJETO AUTOBIOGRÁFICO (1562) Y HAGIOGRÁFICO (1590)}

En la narración que hace Teresa cuarenta años después, al escribir su vida, presenta a su hermano Rodrigo, dos años mayor que ella, como alguien que compartía sus emociones y decisiones de ese momento porque leía los mismos libros. Tendríamos aquí dos ejemplos de subjetividad que, como dirían los posestructuralistas de los años 70, 80 y 90, se van construyendo mediante el lenguaje y los discursos a los que tienen acceso. Esta forma de entender el proceso de subjetivación seguía un modelo unidireccional: el autor, cuya muerte había sido ruidosamente proclamada por Roland Barthes, no existía fuera del texto y por tanto no podía atribuírsele ningún tipo de intencionalidad. Ahora bien, si leemos la autobiografía de Teresa, podemos comprobar que la reconstrucción de los hechos que ofrece no es sólo producto del lenguaje y de los discursos que dieron forma a ese texto, sino que está escrita con la intención de persuadir a sus lectores y ofrecerles un modelo de espiritualidad mucho más accesible que las vidas de santos que circulaban en esa época. No es una cuestión de atribución de intenciones, sino de tener en cuenta que, en el caso de textos como esta autobiografía espiritual, tanto la escritura como la lectura son procesos de interacción: al contar cómo había imitado a los santos sobre los que había leído, la escritora ofrecía a sus lectores un modelo alternativo de imitación, que les podría ayudar a entender sus propias aspiraciones, y sus propios miedos y fracasos.

Si Teresa decidió incluir en su relato autobiográfico este episodio de fallido martirio quizá fue para demostrar que ya desde niña ponía sus miras en el más allá, y quizá también para invitar a sus lectores a pensar en ese "ipara siempre, siempre, siempre!» (Vida 1.5), y ofrecerles la posibilidad de ponerse en su lugar: si a ella le daba miedo pensar en el infierno, y le daba confianza imitar a los santos mártires, sus lectores también podrían pasar del miedo a la confianza. El problema era que imitar a los mártires no estaba al alcance de las niñas cristianas del Ávila en el que le tocó vivir a Teresa, como ella bien sabía. Si quería inspirar miedo y confianza en sus lectores, tendría que contarles detalles de su vida mucho menos heroicos, y que por tanto estaban al alcance de las mujeres.

No sabemos cómo habría leído el episodio del fallido intento de martirio de Teresa el dominico a quien ella le mandó la primera versión de su autobiografía, en 1562, o cómo lo había entendido o vivido la Princesa de Éboli, que al parecer disfrutaba y se reía al leer la segunda versión de ese relato siete años después. Lo que sí tenemos es la lectura comentada que ofrece Ribera en la biografía hagiográfica de Teresa que escribió en 1590, cuando ésta llevaba ocho años muerta y se buscaba canonizarla. En esta biografía, Ribera nos cuenta que cuando Teresa intentó escapar a tierra de moros, tenía siete años, y que ella y su hermano no 
consiguieron llegar mucho más allá de la muralla de Ávila porque les encontró un tío suyo ${ }^{34}$.

A Ribera no le interesaba ver en la autobiografía de Teresa el lento proceso de aprendizaje e individuación que ella había descrito (con el imperfecto «nos dava») como producto de sus lecturas de vidas de santos. Lo que según el texto de Teresa podríamos interpretar como experiencia de miedo al sufrimiento eterno del infierno, y deseo de gozo eterno, para Ribera era una prueba de que: «aun desde entonces tenía mucho ánimo, y era muy determinada para las cosas de Dios, no se contentó con solos deseos» ${ }^{35}$. Al parecer, el posicionamiento de Ribera como hagiógrafo, que intentaba convencer con su reconstrucción de la biografía de Teresa de que ésta merecía ser canonizada, le llevó a atribuir a la Teresa niña un coraje y una determinación que ella había explicado como resultado de su interacción con Dios: «y paréceme que nos dava el Señor ánimo, en tan tierna edad». ${ }^{36}$ Sin embargo, mientras ella, con la modestia que era de esperar de una narración en primera persona, presentaba su ánimo y valentía como resultado de su inter-subjetividad (de su relación con los libros, que le hacían anhelar la presencia de Dios para siempre), Ribera lo presentaría como una característica individual de Teresa, que la diferenciaba de otras niñas y mujeres, y demostraba su excepcionalidad.

\section{MIEDO AL INFIERNO COMO GUÍA DE COMPORTAMIENTO: ENTRADA EN EL CONVENTO}

Sabemos que Teresa cayó enferma en 1533, y, pasó unos días en Hortigosa con un tío suyo fraile que le habló de aspiraciones espirituales y le hizo leer libros devocionales. Uno de los libros de mayor éxito comercial de aquel momento era la Segunda parte del abecedario espiritual, de Francisco de Osuna, publicado en

34. Ribera, Francisco de: Vida de la madre Teresa de Jesús [Salamanca, 1590], edición preparada por J. Pons. Barcelona, 1908, p. 96. La vivencia subjetiva de Teresa pasó, poco después de su muerte, a formar parte del imaginario colectivo, como puede verse en los numerosos grabados y versiones pictóricas que se harían del episodio de su huida fallida; véase por ejemplo el tercero de los grabados de Adriaen Collaert y Corneille Galle en Vita B. Virginis Teresiae a Iesu. Amberes, 1613; edición facsímil en Pinilla, María José (Ed.): Estampas de la Vida de la Santa Madre Teresa de Jesús grabadas por los famosos artistas Cornelio Galle y Adrián Collaert, impresas en Amberes en 1613. Madrid, 2012. Lo que empezó como proceso de subjetivación de Teresa a través de sus lecturas de vidas de santos continuó reproduciéndose en marcos sociales nuevos, como se ve en un cuadro de 1700 del Museo Tejeda de Córdoba, atribuido al taller de Juan Espinosa de los Monteros, de la Escuela de Cuzco, que reconstruye el episodio de la huida fallida de Teresa con un trasfondo que representa a las Américas.

35. Ribera: Vida de la madre Teresa, p. 96.

36. Vida, 1.5, p. 35. 
1530 y reeditado cinco veces. En ese libro, como en otros de la época, se invitaba a lectores y predicadores a que imaginaran (e hicieran imaginar) las penas del infierno para fomentar un miedo que se presentaba (o construía) como algo positivo:

Y los que allá están para siempre serán atormentados, que es la cosa que más debe mirar el temor para della comprar espanto y miedo de ofender al que no solamente puede echar el ánima y el cuerpo en el infierno, mas justamente los atormentará sin darles algún descanso ni fin, lo qual es la cosa de que el temor se deve más espantar y traer la mercaduría del miedo de las cosas dichas metida en los huesos, viendo la pena sin descanso y la muerte sin muerte, pues muriendo nunca mueren, y la vida sin vida, pues viviendo siempre mueren, y viendo el fuego que siempre arde, y el frío que del fuego no se favorece, y el gusano que siempre roe y los carcome de dentro, el humo causador de lágrimas, el hedor tan renovado que, siempre, como de nuevo atormenta, las tinieblas espantosas en que aún no se conocen, el espanto que unos a otros se causan, los lazos en que todos caen, los martillos que a todos hieren, la pobreza sin remedio, la pestilencia sin medicina, el hambre con que se comen sus miembros sin se hartar, la sed con que se quieren bever la sangre ${ }^{37}$.

Podemos entender las recomendaciones de Osuna en los términos que propondría Scheer en 2012, al hablar de «prácticas emocionales», entendidas como:

hábitos, rituales, y pasatiempos cotidianos que nos ayudan a conseguir un estado emocional determinado. A veces se trata de esforzarse uno por llegar a sentir lo que uno desea; otras veces se trata de modificar el sentimiento no deseado [...] En otras palabras, [las prácticas emocionales] son parte de lo suele denominarse «regulación de las emociones» y del aprendizaje y mantenimiento continuos de un repertorio emocional ${ }^{38}$.

Si el pensar en las penas del infierno, siguiendo las pautas de Osuna y otros predicadores de esa época, hacía que el miedo se le metiera a uno en los huesos, se habría conseguido un estado emocional deseado, en la medida en la que ayudara a modificar comportamientos no deseados (el pecado, u ofensa a Dios). De igual modo, en los Ejercicios espirituales, escritos en París hacia 1535, Ignacio de Loyola establecía la meditación sobre el infierno como quinto ejercicio de la primera

37. Osuna, Francisco de: Segunda parte del libro llamado abecedario spiritual [sic]. Sevilla, 1530 , fol. $55 \mathrm{v}$.

38. Scheer: «Are Emotions a Kind of Practice?», p. 216: «Emotional practices are habits, rituals, and everyday pastimes that aid us in achieving a certain emotional state. This includes the striving for a desired feeling as well as the modifying of one that is not desirable [...] in other words, [emotional practices] are part of what is often referred to as «emotional management» and the ongoing learning and maintaining of an emotional repertoire». 
semana, y recomendaba que se empezara por pedirle a Dios la capacidad de sentir las penitencias de los condenados, como método preventivo para evitar el pecado:

pedir interno sentimiento de la pena que padescen los dañados, para que si del amor del Señor eterno me olvidare por mis faltas, a lo menos el temor de las penas me ayude para no venir en pecado ${ }^{39}$.

En el Libro de la oración y meditación, publicado en 1554, 1556, 1559 y en numerosas ediciones hasta finales del siglo XIX, Fray Luis de Granada se apoyaba en la autoridad de Ricardo de San Víctor al sugerir que el pensar en las penas del infierno era un método eficaz para combatir deseos pecaminosos:

Aprovecha también (como dize Richardo) para vencer las tentaciones del enemigo, quando a Ia primera entrada del mal pensamiento ponemos luego delante el horror destas penas y apagamos la llama del deleyte antes que arda con la memoria de las llamas que nunca se apagarán ${ }^{40}$.

Tendríamos aquí un ejemplo del impacto del contexto socio-cultural sobre el cuerpo, que Arlie Hochschild describiría en términos generales en 1983:

Cuanto más tiempo permanece una persona en un ambiente, tanto más se le inscriben en el cuerpo las normas prevalentes sobre lo que debe sentirse, influyendo en gran medida su comportamiento general ${ }^{41}$.

39. Ejercicios espirituales, núm. 65, Loyola, Ignacio de: Obras completas de San Ignacio de Loyola, $3^{a}$ edición, preparada por Ignacio Iparraguirre y Cándido Dalmases. Madrid, 1977, pp. 169-303 (226). Como señala Araceli Guillaume-Alonso, la evocación del infierno como consecuencia del pecado y de la falta de arrepentimiento ocuparon un lugar central en la predicación postridentina, que ponía el énfasis en el sacramento de la confesión; los jesuitas jugaron un papel clave en ese contexto; véase Guillaume-Alonso, Araceli: «Enfer et damnation dans la pastorale jésuite au XVIe siècle», en Duviols; Moliné-Bertrand (Coords.): Enfers, pp. 247-261 (260). Véanse también Chinchilla Pawling, Perla: «Predicación y miedo», en Gonzalbo Aizpuru; Staples; Torres Septién (Coords.): Una historia de los usos del miedo, pp. 203-221; Nava Sánchez, Alfredo: «Es por meter miedo a los hombres: el miedo al infierno en el siglo XVI novohispano», en ibidem, pp. 185-202; Rovira, Juan: «La meditación del infierno y los ejercicios espirituales de San Ignacio y la Sagrada Escritura», Manresa, 3, 1927, pp. 221-216; Roldán Viller, Alejandro: «La afectividad en la ascética ignaciana», Manresa, 53, 1981, pp. 33-54.

40. Granada, Luis: Libro de la oración y meditación. Amberes, 1559, fol. 146r. Éste es otro de los libros que Teresa recomendaría en las Consituciones.

41. La cita es de Gammerl, Benno: «Emotional Styles - Concepts and Challenges», Rethinking History: The Journal of Theory and Practice, 16:2, 2012, pp. 161-175 (167): «the longer a person lingers within a certain environment, the deeper the corresponding feeling rules become inscribed in her body, thus strongly influencing her overall conduct». Véanse Hochschild, Arlie: The Managed Heart: Commercialization of Human Feeling. Berkeley, 1983; Hochschild: «Emotion work, feeling rules, and social structure», American Journal of Sociology, 85, 1979, pp. 551-575. 
Con lecturas de libros devocionales como los de Osuna, y con las conversaciones que Teresa tuvo con su tío en la primavera de 1533, volvieron a ella los temores de la infancia al pensar en el infierno. Según relataría en su autobiografía, llegó a estar convencida de que si moría en ese momento se iría directa al infierno:

Aunque fueron los días que estuve pocos, con la fuerza que hacían en mi corazón las palabras de Dios, ansí leídas como oídas, y la buena compañía, vine a ir entendiendo la verdad de cuando niña, de que no era todo nada, y la vanidad del mundo, y cómo acabava en breve, y a temer, si me hubiera muerto, cómo me iva al infierno ${ }^{42}$.

Con la evidencia histórica que nos ofrecen textos como los de Osuna, que prescriben el miedo al infierno, y como los de Teresa, que describen los efectos de ese miedo, podemos entenderlo como un miedo colectivo, que llegaba a afectar a las relaciones entre individuos, así como a la relación que podían establecer los individuos más reflexivos consigo mismos, o consigo mismas.

Al mirar hacia atrás, desde el momento de la escritura en 1562, y explicar por qué se había metido monja en lugar de seguir con sus devaneos amorosos, y casarse, como lo hicieron sus amigas de la adolescencia, Teresa presenta su decisión como la opción que en aquel momento le pareció el mejor antídoto para combatir el miedo al infierno y el miedo al purgatorio:

Y aunque no acabava mi voluntad de inclinarse a ser monja, vi era el mejor y más siguro estado; y ansí poco a poco me determiné a forzarme para tomarle.

En esta batalla estuve tres meses, forzándome a mí misma con esta razón: que los travajos y pena de ser monja no podía ser mayor que la del purgatorio, y que yo había bien merecido el infierno; que no era mucho estar lo que viviese como en purgatorio, y que después me iría derecha al cielo, que éste era mi deseo ${ }^{43}$.

Según afirmaría Fray Luis de Granada, el pensar en los sufrimientos eternos del infierno había servido como aliciente a los santos a la hora de elegir su forma de vida:

la consideración de las penas del infierno es en gran manera prouechosa para muchas cosas. Lo primero para movernos a los trabajos y asperezas de la penitencia, como se mouía el bienaventurado sant Hierónymo; el qual dize de sí mismo, que por el gran miedo que auía concebido de las penas del infierno se auía condenado a hazer tan áspera penitencia como él allí describe que hazía en aquel desierto ${ }^{44}$.

Según nos cuenta Teresa, la lectura de las Epistolas de San Jerónimo es lo que le había dado fuerzas para salir de casa de noche, a escondidas, y entrar en el

42. Vida 3.5 , p. 40.

43. Vida 3.5-6, p. 40.

44. Libro de la oración, fol. 146r. 
convento de la Encarnación de Ávila. Lo que no cuenta, porque no era relevante para su autobiografía espiritual, es que mientras ella se debatía sobre si entrar o no en un convento, dos de sus hermanos, Hernando en 1533 y Rodrigo en 1535, se embarcaron, decididos a alcanzar la heroicidad en la conquista de Perú ${ }^{45}$. Ella, con 20 años, se había quedado en casa por ser mujer, sin otro apoyo que el de los libros.

Si en aquel momento el querer ser héroe guerreando en el Perú le estaba vedado a las mujeres, éstas podían buscar la heroicidad combatiendo el miedo al infierno, que en principio no establecía desigualdades sociales, o al menos no parecía diferenciar entre ricos y pobres, niños y mayores, hombres y mujeres, o letrados y analfabetos. Al fin y al cabo, el miedo al infierno era una forma de miedo intersubjetivo que trascendía los límites corporales porque lo que se temía no era el peligro de resultar herido o de morir.

Sin embargo, mientras siete de los hermanos de Teresa podían protegerse del miedo al infierno luchando por la cristianización de los indios, a ella y al resto de las mujeres nada podía protegerlas de ese miedo. Ni siquiera el convento, donde ella había esperado encontrar en 1535 la protección de barreras físicas que le ayudaran a combatir sus deseos mundanos. Al parecer, las monjas no sólo no podían permitirse permanecer aisladas de la sociedad, sino que además dependían de los donativos de los jóvenes nobles que solían buscar conversación y entretenimiento en el locutorio. Echando la vista atrás en 1562, cuando intentaba crear un espacio alternativo fundando un convento de clausura estricta, Teresa aludía al infierno para convencer a sus lectores de la conveniencia de ésta:

Por esto me parece a mí me hizo harto daño no estar en monesterio encerrado; [...], para mí, que soy ruin, huviérame cierto llevado a el infierno, si con tantos remedios y medios el Señor con muy particulares mercedes suyas no me huviera sacado de este peligro. $\mathrm{Y}$ ansí me parece lo es grandísimo, monesterio de mujeres con libertad; y que más me parece es paso para caminar al infierno las que quisieren ser ruines, que remedio para sus flaquezas ${ }^{46}$.

Los argumentos de Teresa sobre lo peligrosos que podían resultar los conventos convencionales resultarían más persuasivos para sus contemporáneos, que estaban expuestos al miedo colectivo al infierno, que para lectores y lectoras de hoy en día que no compartimos ese miedo. El infierno forma parte de un imaginario colectivo que parece quedar lejano, pero que fue reproduciéndose textual

45. Sobre el viaje a las Indias de siete de los hermanos de Teresa y de sus sobrinos Francisco y Lorenzo, véanse Alabrús, Rosa Maria; García Cárcel, Ricardo.: Teresa de Jesús: La construcción de la santidad. Madrid, 2015, pp. 210-211; García Cárcel: «Los tiempos recios de Teresa de Jesús», en Callado Estela (Coord.): Viviendo, pp. 13-41 (18-20).

46. Vida, 7.3, p. 53. 
y pictóricamente en la cultura occidental hasta bien avanzado el siglo XX, desde textos claves, como la Biblia, en la que se describe como un lago de azufre y fuego, o la Ciudad de Dios de San Agustín, donde se argumenta que el alma mantiene la sensibilidad tras la muerte, hasta pinturas de reconocidos artistas como El Bosco y Miguel Ángel, o grabados como los de Lucas Cranach en el contexto de la lucha de Lutero contra la iglesia de Roma.

En la época de Teresa, la meditación sobre las penas del infierno era una práctica ascética bastante extendida, que recomendaban los tratados devocionales populares, como el Vita Christi:

Allí avrá ardor de huego [sic], rigor de frío, humo de tinieblas, lágrimas interiores, vista e presencia continua de los demonios, clamor de rauiosas y perdurables bozes, martillos de atormentadores, serpientes e dragones, sequedad de mortal sed, hedor de piedra çufre, gusano remordedor de consciencia, cadenas, cárcel, temor, dolor, vergüenza e confusión de los peccados, los quales serán manifiestos a todos, embidia, rancor, tristeza, engagenamiento dela cara de dios, perdimiento de toda esperança de salud ${ }^{47}$.

En los Ejercicios espirituales, Ignacio de Loyola invitaba a meditar sobre el infierno de forma estructurada, centrándose en cada uno de los cinco sentidos: tras un preámbulo, que consistía en «ver con la vista de la imaginación la longura, anchura y profundidad del infierno», uno debía ejercitarse en «ver con la vista de la imaginación los grandes fuegos, y las ánimas como en cuerpos ígneos», en «oír con las orejas llantos, alaridos, voces, blasfemias contra Christo nuestro Señor y contra todos sus santos», en "oler con el olfato humo, piedra azufre, sentina y cosas pútridas», en "gustar con el gusto cosas amargas, así como lágrimas, tristeza y el verme de la consciencia», y en «tocar con el tacto, es a saber, cómo los fuegos tocan y abrasan las ánimas» ${ }^{4}$.

En el Libro de la oración, Fray Luis de Granada, basándose en las meditaciones atribuidas a Buenaventura, recomendaba:

ymaginar el lugar del infierno [...] como vn lago escuro y tenebroso, puesto debaxo de la tierra, o como vn pozo profundíssimo lleno de fuego, como vna ciudad espantable y tenebrosa, que toda arde en bivas llamas, en la qual no suena otra cosa sino bozes y gemidos de atormentadores y atormentados con perpetuo llanto y cruxir de dientes ${ }^{49}$.

47. Ludolfo de Sajonia: Vita Christi cartuxano romançado por fray Ambrosio [Montesino]: la quarta parte. Alcalá de Henares, 1503, fol. 283v.

48. Ejercicios, núms. 65-70, p. 226; véase Nicolás, Antonio T. de: Powers of Imagining. Ignatius de Loloya: A Philosophical Hermenentic of Imagining through the Collected Works of Ignatius of Loyola. Albany, NY, 1986.

49. Libro de la oración, fol. $143 \mathrm{v}$. 
Granada explicaba que los castigos del infierno afectarían a cada uno de los sentidos externos, y a cada uno de los sentidos internos (imaginación, memoria y entendimiento). Los ojos «serán atormentados con la visión horrible de los demonios», los oídos con «la confusión de las bozes y gemidos que allí sonarán», «las narizes, con el hedor intolerable de aquel suzio lugar», el gusto con "grandísima hambre y sed», y el tacto y todo el cuerpo con «frío y fuego incomportable»; el fuego, como explicaba San Gregorio, no se apagaría nunca, y las tinieblas serían "palpables» ${ }^{50}$. Como apuntaba San Agustín, el fuego del infierno arde sin consumirse y es «de tan gran ardor y efficacia» que, en comparación con él, «este nuestro de acá, es como pintado». ${ }^{51}$ Para entender estos castigos, Granada proponía hacer un ejercicio de la imaginación basado en las sensaciones corporales:

Y para que mejor esto puedas entender, párate a ymaginar lo que sentirías si te echassen en una grande cal[d]era, quando ella estuuiesse más viva y más encendida, o en algún grande horno de fuego, qual era aquél que encendió Nabuchodonosor [Dan. 3] en Babylonia, cuyas llamas subían quarenta y nueve codos en alto, y por aquí podrás barruntar algo de lo que allí se pasará. Porque si este nuestro fuego que (según diximos) es como pintado, assí atormenta, ¿qué hará aquél que es verdadero? $[\ldots]$

Con esta pena se juntará otra contraria a ella, aunque no menos intolerable, que será un horrible frio, que con ninguno de los nuestros se puede comparar, el qual se dará por miserable refrigerio a los que arden en aquel fuego, pasándolos (como se escriue en Job) de las aguas de nieve [Job 24:14] a los calores del fuego, para que no quede ningún género de tormento por prouar, a los que ningún género de deleyte quisieron dexar de gustar ${ }^{52}$.

Para hacerse idea de cómo sería el temor que se sentiría en el infierno al ver el lago tenebroso y la horrible figura del demonio, Granada sugería que se tuviera en cuenta la capacidad de los sentidos y la imaginación para producir alteraciones fisiológicas:

nos consta que algunas personas han perdido el sentido, y aun muerto de espanto con la vista o ymaginación de algunas cosas temerosas, y a veces la sospecha sola dellas, nos hace erizar los cabellos y temblar ${ }^{53}$.

La explicación que daba Granada de cómo sería castigado el sentido del olfato estaba encaminada a eliminar el deseo de presumir y ser ostentoso:

50. Libro de la oración, fol. $144 \mathrm{r}$.

51. Libro de la oración, fol. $147 \mathrm{v}$.

52. Libro de la oración, fols. $147 \mathrm{v} .-148 \mathrm{r}$.

53. Libro de la oración, fol. 148r. 
Al tormento de los ojos se añade otra pena terrible para las narizes, que será vn hedor incomportable que aurá en aquel lugar para castigo de los olores y atauíos que los hombres carnales y mundanos buscaron en este mundo, como lo amenaza Dios por Isaías, diciendo [Is. 3]: Porque se envanecieron las hijas de Syón, y anduvieron los cuellos leuantados, alconeando con los ojos, y pauoneándose en su passear, haciendo alarde de sus pompas y riquezas entre los flacos y desnudos, por tanto el Señor les pelará los cabellos de la cabeça, con todos los otros atauíos prophanos, y darles ha en lugar de los suaues olores, hedor, y en lugar de la cinta vna soga, y en lugar de los cabellos hondeados la calua pelada, y en lugar de la faxa de los pechos vn silicio. Esta es la pena que se deue a los olores y atavíos de los hombres mundanos ${ }^{54}$.

Por si el miedo a perder el pelo y a sentir un olor insoportable no resultaba lo suficientemente persuasivo, Granada comparaba también las penas del infierno a una forma de tortura que de seguro produciría horror en quienes la visualizaran y meditaran sobre ella:

Para sentir algo desta pena párate a considerar aquel tan horrible género de tormento, que vn tirano crudelíssimo inuentó para justiciar los hombres, el qual tomando vn cuerpo muerto, mandáualo tender sobrevn biuo, y atando muy fuertemente al biuo con el muerto, dexáualo estar assí juntos, hasta que el muerto matasse el biuo con la hediondez, y gusanos que dél salían. Pues si te parece muy horrible este tormento, dime: ¿qué tal será aquél que procederá del hedor de todos los cuerpos de los condenados, y de aquél tan abominable lugar donde los malos estarán? Allí se dirán a cada uno de los miserables aquellas palabras de Isaías [Is. 14]: Descendió hasta los infiernos tu soberuia, y allí cayó tu cuerpo muerto: debaxo de ti se tenderá la polilla, y la cubija que ternás encima, serán gusanos ${ }^{55}$.

Para ayudar a entender sensorial y emocionalmente el efecto atroz de las «perpetuas bozes, y clamores, y gemidos, y blasphemias», la «desacordada melodía de infinitas bozes desyguales que allí se cantan al sonido de los martillos y golpes de los verdugos», y de los grandes alaridos con los que serían atormentados lo oídos en el infierno, Granada recomendaba situarse con la imaginación en un lugar profundo en el que se escucharan ruidos espantosos:

Para sentir algo desta pena, ymagina agora que passasses por vn valle muy hondo, el qual estuuiesse lleno de vna infinita muchedumbre de captiuos, y heridos, y enfermos, y que todos ellos estuuiessen dando gritos y bozes cada vno de su manera, assí hombres como mujeres, como niños y como viejos. Dime: ¿qué parescería este ruydo tan grande y de tanta confusión? ¿Pues qué parescerá aquel espantoso ruydo

54. Libro de la oración, fols. 148v.-149r.

55. Libro de la oración, fol. 149r. 
de tan gran número de condenados, los quales perpetuamente otra cosa no harán sino gritar, y blasphemar, y renegar de Dios, y de sus sanctos? ${ }^{56}$

La imaginación no sólo sería castigada mediante un sentimiento de dolor tan intenso que no le permitiría distraerse de él, sino que además haría que el dolor se intensificara:

La ymaginación será allí atormentada con vna tan vehemente aprehensión de aquellos dolores, que en ninguna otra cosa pensará, ni podrá pensar. Porque si vemos que quando vn dolor es agudo no podemos aunque queramos apartar el pensamiento dél, porque el mismo dolor despierta la ymaginación para que otra cosa no piense sino lo que le duele, ¿quánto mas acaescerá esto allí donde el dolor es sin comparación más intolerable? Desta manera la ymaginación abiuará el dolor, y el dolor a la ymaginación, para que assí por todas partes crezca el tormento del condenado. Estas serán las meditaciones continuas de aquéllos que nunca quisieron mientras biuían acordarse destas penas, para que los que no las quisieron pensar aquí para freno de su vida, las padezcan allí para castigo de su culpa ${ }^{57}$.

Como podemos comprobar, las meditaciones sobre el infierno, a las que exhortaban Granada y otros predicadores, formaban parte de la experiencia cultural de Teresa, apoyadas por las representaciones del infierno que se podían contemplar en las pinturas de las iglesias y en los grabados de los libros devocionales. Sin embargo, según el testimonio de Teresa en uno de los capítulos de la autobiografía que añadió en la segunda versión, de 1565, en realidad a ella el pensar en los sufrimientos del infierno de los que hablaban los libros no le había producido demasiado efecto:

Porque no es nada oírlo decir, ni haver yo otras veces pensado en diferentes tormentos (aunque pocas, que por temor no se llevaba bien mi alma), ni que los demonios atenazan, ni otros diferentes tormentos que he leído, no es nada con esta pena, porque es otra cosa. En fin, como de debujo a la verdad, y el quemarse acá es muy poco en comparación de este fuego de allás ${ }^{58}$

Según la experiencia de Teresa, lo que se podía entender escuchando, mirando, leyendo o pensando apenas tenía valor en comparación con lo que se podía entender sintiendo. Ella ofrecía a sus lectores un punto de vista privilegiado, tras haber tenido una intensa experiencia sensorial y emocional del infierno en una de sus visiones, en 1559:

56. Libro de la oración, fol. $149 \mathrm{v}$.

57. Libro de la oración, fols. 150r-v.

58. Vida 32.3, p. 174. 
Estando un día en oración, me hallé en un punto toda, sin saber cómo, que me parecía estar metida en el infierno. Entendí que quería el Señor que viese el lugar que los demonios allá me tenían aparejado, y yo merecido por mis pecados. Ello fue en brevísimo espacio, mas aunque yo viviese muchos años, me parece imposible olvidárseme.

Basándose en esta experiencia mental, vivida desde el cuerpo, Teresa podía explicar mejor que ninguno de los predicadores cómo eran las penas del infierno:

Parecíame la entrada a manera de un callejón muy largo y estrecho, a manera de horno muy bajo y escuro y angosto; el suelo me pareció de un agua como lodo muy sucio y de pestilencial olor, y muchas sabandijas malas en él; a el cabo estaba una concavidad metida en una pared, a manera de una alacena, adonde me vi meter en mucho estrecho.

Si Granada había descrito el fuego como el de un gran horno, Teresa evocaba ese fuego como una sensación indescriptible:

Todo esto era deleitoso a la vista en comparación de lo que allí sentí. Esto que he dicho va mal encarecido. Estotro me parece que aun principio de encarecerse cómo es no le puede haver, ni se puede entender; mas sentí un fuego en el alma, que yo no puedo entender cómo poder decir de la manera que es.

Lo que sintió durante la visión del infierno no era comparable ni con el intenso dolor físico que había sentido en los tres años en que había permanecido tullida (1539-1542), ni con el que había sufrido durante experiencias que ella había interpretado como efecto de la acción del demonio:

Que, con haverlos pasado en esta vida gravísimos y, sigún dicen los médicos, los mayores que se pueden acá pasar (porque fue encogérseme todos los nervios cuando me tullí, sin otros muchos de muchas maneras que he tenido y aun algunos, como he dicho, causados de el demonio).

El pensar en que el dolor no se acabaría nunca lo hacía aún más intenso: «no es todo nada en comparación de lo que allí sentí, y ver que havían de ser sin fin y sin jamás cesar». Tenemos aquí un ejemplo de cómo el dolor no es algo objetivo, sino que depende de cómo se perciba dentro de un marco ideológico compartido. Teresa, al igual que Loyola y Granada, diferenciaba entre dolor físico y dolor psíquico:

Esto no es, pues, nada en comparación del agonizar de el alma: un apretamiento, un ahogamiento, una afleción tan sentible y con tan desesperado y afligido descontento, que yo no sé cómo lo encarecer.

Sin embargo, Teresa iba más allá que los predicadores al describir el desgarro psíquico que sintió en esa premonición de lo que sería el infierno: «porque decir 
que es un estarse siempre arrancando el alma, es poco, porque aun parece que otro os acaba la vida; mas aquí el alma misma es la que despedaza» ${ }^{59}$. Desde la posición de autoridad que le daba esa visión (que ella estaba convencida de haber recibido de Dios), aseguraba que no había desesperación igual a la que se sentiría en el infierno:

El caso es que yo no sé cómo encarezca aquel fuego interior y aquel desesperamiento sobre tan gravísimos tormentos y dolores. No vía yo quién me los dava, mas sentíame quemar y desmenuzar, a lo que me parece. Y digo que aquel fuego y desesperación interior es lo peor ${ }^{60}$.

Explicaba de forma muy gráfica que en el infierno no hay descanso ni espacio, y que el horror no se sentía sólo con los sentidos, sino que producía una sensación de aplastamiento y ahogo que afectaba a todo el cuerpo:

Estando en tan pestilencial lugar, tan sin poder esperar consuelo, no hay sentarse ni echarse, ni hay lugar, aunque me pusieron en éste como agujero hecho en la pared; porque estas paredes, que son espantosas a la vista, aprietan ellas mesmas, y todo ahoga. No hay luz, sino todo tinieblas escurísimas. Yo no entiendo cómo puede ser esto, que con no haber luz, lo que a la vista ha de dar pena todo se ve.

El horror que se sentía al involucrarse corporal y emocionalmente en la experiencia premonitoria de las penas del infierno era incomparablemente superior al horror que se pudiera sentir al contemplar esos castigos:

No quiso el Señor entonces viese más de todo el infierno; después he visto otra visión de cosas espantosas, de algunos vicios el castigo. Cuanto a la vista, muy más espantosos me parecieron, mas como no sentía la pena, no me hicieron tanto temor; que en esta visión quiso el Señor que verdaderamente yo sintiese aquellos tormentos y aflicción en el espíritu como si el cuerpo lo estuviera padeciendo.

El impacto de esta visión fue tal, que al describirla seis años después Teresa volvió a sentir un gran miedo en el cuerpo: «yo quedé tan espantada, y aún lo estoy ahora escriviéndolo, con que ha casi seis años, y es así que me parece el

59. Vida 32.2, p. 173. Domique de Courcelles sugiere que al cambiar del pasado de la narración al presente de «se despedaza», Teresa consigue crear una impresión más fuerte de su «afleción de espíritu», marcada por una experiencia aterradora que continúa viva en su memoria; véase Courcelles, Dominique de: «La pensée de l'enfer dans le Libro de la vida de Thérèse d'Avila», en Duviols; Moliné-Bertrand (Coords.): Enfers, pp. 231-245 (237).

60. Vida 32.2, p. 173. La noción de la desesperación como parte de los castigos del infierno, propuesta por San Agustín, había sido controvertida, pero terminó por imponerse a finales de la Edad Media, al ser adoptada por Santo Tomás de Aquino (In IV Sent, dist. XLV, qu. 2, art. 2, 1.1); véase Courcelles: «La pensée», p. 237. 
calor natural me falta de temor aquí adonde estoy» ${ }^{61}$. Al escribir sobre el miedo al infierno desde el punto de vista de su experiencia personal, Teresa ofrecía a sus lectores la posibilidad de adentrarse momentáneamente en esa experiencia sensorial y emocional, simulando, con la parte perceptual y motora del cerebro, las vivencias que ella contaba con todo detalle. Su evocación del miedo como experiencia que dejaba el cuerpo frío, y su alusión al calor natural que daba vida al cuerpo según las teorías médicas y de filosofía natural vigentes en el siglo XVI, parece una forma más eficaz de provocar miedo en los lectores que las representaciones pictóricas y las imágenes visuales que utilizaban los predicadores y escritores devocionales de la época. Si pensamos, desde el punto de vista que sugiere Ahmed, en qué «hace» el texto, qué efecto produce sobre los lectores, es obvio que debemos distinguir entre diferentes tipos de lectores, situados en diferentes contextos históricos y culturales. Para los lectores del siglo XVI, que habían oído hablar con frecuencia del infierno, el testimonio que ella ofrecía sobre lo que había sentido sería más persuasivo que las palabras de las exhortaciones de Osuna y Loyola o las descripciones de Granada. Los contemporáneos de Teresa que pudieran leer el relato de su vida podrían identificarse no ya con cuerpos lejanos, de frescos y grabados, sino con los sentimientos de una mujer que vivía entre ellos ${ }^{62}$.

Además, Teresa también ofrecía una alternativa al punto de vista de Osuna de que convenía cultivar el miedo («comprar espanto y miedo»), al mostrarse confiada en que no iría al infierno, no por lo que ella hubiera hecho o dejado de hacer, sino porque sentía que Dios la apoyaba:

Y ansí no me acuerdo vez que tengo travajo ni dolores, que no me parece nonada todo lo que acá se puede pasar. Y ansí me parece, en parte, que nos quejamos sin propósito. Y ansí torno a decir que fue una de las mayores mercedes que el Señor me ha hecho, porque me ha aprovechado muy mucho, ansí para perder el miedo a las tribulaciones y contradicciones de esta vida, como para esforzarme a padecerlas y dar gracias a el Señor que me libró, a lo que ahora me parece, de males tan perpetuos y terribles.

61. Vida 32.3-4, pp. 173-174.

62. En ese sentido, la descripción del infierno que ofrece Teresa es más eficaz que las de la mayoría de las fuentes escritas de la época. Para Javier Portús, éstas son menos pormenorizadas y anecdóticas, y más abstractas que las representaciones pictóricas; Portús Pérez, Javier: «Infiernos pintados: iconografía infernal en la Edad Moderna hispánica», en Tausiet; Amelang (Coords.): El Diablo, pp. 253-275 (256). Sin embargo, esta distinción no parece del todo válida si tenemos en cuenta lo detalladas y anecdóticas que pueden llegar a ser las descripciones textuales del infierno, como vemos en los pasajes de Granada, de Teresa, o del autor del Vita Christi cartuxano que cito en este artículo. 
Después acá, como digo, todo me parece fácil en comparación de un memento que se haya de sufrir lo que yo en él allí padecí. Espántame cómo haviendo leído muchas veces libros adonde se da algo a entender las penas de el infierno, cómo no las temía ni tenía en lo que son. ¿Adónde estava? ¿Cómo me podía dar cosa descanso de lo que me acarreaba ir a tan mal lugar? ${ }^{63}$

En este pasaje, Teresa daba a entender que, a pesar de la insistencia de los libros, ella no había actuado por miedo al infierno, sino que había mantenido la confianza en Dios. En lugar de temer el infierno e intentar persuadir a sus lectores de que lo temieran, prefería ver la parte positiva: el pensar en sensaciones horribles y emociones terribles, como la suma desesperación que había sentido en la visión del infierno, le ayudaba a relativizar las dificultades del día a día.

Las mayores «tribulaciones y contradicciones» de Teresa no fueron las prácticas de mortificación con las que se le asociaría en varias de las representaciones pictóricas y grabados que se hicieron de ella desde el momento de su canonización en el siglo $\mathrm{XVII}^{64}$. Tampoco fueron las graves enfermedades y los padecimientos físicos que la aquejaron desde 1532, un año antes de entrar en el convento. Fue el no tener con quien compartir lo que sentía durante las prácticas de meditación y contemplación mística que aprendió de otro libro de Osuna, el Tercer abecedario espiritual, que empezó a leer en 1538 y que ninguno de sus confesores conocía. Se pasó la cuarta parte de su vida aislada psíquica y espiritualmente: «Duré en esta ceguedad creo más de diecisiete años, hasta que un Padre dominico, gran letrado, me desengañó en cosas, y los de la Compañía de Jesús del todo me hicieron tanto temer» ${ }^{65}$.

\section{EL MIEDO AL DEMONIO COMO EXPERIENCIA INTERSUBJETIVA}

Tras casi dos décadas de poner en práctica las instrucciones de Osuna, Teresa comenzó a tener visiones y a temer que fueran inspiradas por el demonio:

Yo, como en estos tiempos havían acaecido grandes ilusiones en mujeres y engaños que las havía hecho el demonio, comencé a temer, como era tan grande el deleite y suavidad que sentía ${ }^{66}$.

63. Vida 32.4-5, p. 174.

64. Véase por ejemplo el séptimo de los grabados de Collaert y Galle en Pinilla (Ed.): Estampas.

65. Vida 5.3, p. 46.

66. Vida 23.2, p. 126. Todavía se recordaba el caso de Magdalena de la Cruz, priora de las clarisas de Córdoba, cuyas revelaciones habían resultado ser fraudulentas, según ella misma confesó en 1546; véase Vázquez de Prada, Valentín: «La reforma teresiana y la España de su tiempo», en Castro Calvo, José María (Coord.): Santa Teresa en el IV centenario de la reforma carmelitana. Barcelona, 1963, pp. 81-96. Además, desde el Edicto de los Alumbrados de 1525, 
A diferencia del miedo al infierno, el miedo al demonio sí que ha llevado consigo desigualdades de género ${ }^{67}$. La creencia, propagada a través del episodio bíblico del Génesis y de sus comentaristas a través de los siglos, de que la mujer estaba más expuesta a las tentaciones del demonio que los hombres tenía consecuencias prácticas: no sólo se recomendaba que se temiera a las mujeres por ese motivo, sino que también se alentaba en ellas la inseguridad. En este sentido, la evidencia que ofrece la autobiografía de Teresa de cómo se comparó y la compararon con otras mujeres a quienes se veía como víctimas de «ilusiones» o engaños demoniacos (y a quienes se castigaba o marginaba por ese motivo) puede servir para apoyar la teoría de Ahmed sobre las emociones como herramientas sociales que suelen utilizarse para generar, legitimar y aceptar la desigualdad social.

Además, si bien el miedo al demonio puede verse como una experiencia colectiva, cabe destacar que ese tipo de experiencias colectivas no afectan a todos los miembros de un grupo por igual. Por un lado, hay individuos con mayor capacidad de sugestionarse, y verse a sí mismos (o mismas) como víctimas, como parece haber sido el caso de Teresa en 1554: «yo era temerosa en estremo, como he dicho. Ayudávame el mal de corazón, que aun en una pieza sola no osaba estar de día muchas veces» ${ }^{68}$. Por otro lado, hay quienes están en mejor posición que otros para controlar los peligros con los que se asocian esos miedos, o que tienen mayor autoridad a la hora de medir los riesgos, y decidir quién y cuándo está en peligro. Por ejemplo, el clérigo a quien Teresa pidió ayuda, Gaspar Daza, canónigo de la catedral de Ávila, tenía la suficiente autoridad para que nadie cuestionara su opinión de que el método de meditación que ella seguía ponía en peligro su alma porque abría las puertas a la inspiración demoniaca ${ }^{69}$.

la Inquisición había promovido el miedo a todo tipo de oración mental, que se veía como una invitación a la inspiración demoniaca y como una fuente de ideas heréticas; véanse Márquez, Antonio: Los Alumbrados. Orígenes y filosofía, 1525-1559. Madrid, 1972; Hamilton, Alastair: Heresy and Mysticism in Sixteenth-Century Spain. Toronto, 1992; Hamilton: "The alumbrados: Dejamiento and its Practitioners», en Kallendorf, Hilary (Coord.): A New Companion to Hispanic Mysticism. Leiden/Boston, 2010.

67. Mackay, Angus; Wood, Richard.: «Mujeres diabólicas», en Graña Cid, María del Mar; Muñoz Fernández, Ángela (Coords.): Religiosidad femenina: expectativas y realidades (ss. VII-XVIII). Madrid, 1991, pp. 187-196; Moncó Rebollo, Beatriz: Mujer y demonio: una pareja barroca (treinta monjas endemoniadas en un convento). Madrid, 1989; Moncó Rebollo: «Demonios y mujeres: historia de una transgresión», en Tausiet; Amelang (Coords.): El Diablo, pp. 187-210; Martínez-Burgos García, Palma: «Lo diabólico y lo femenino en el pensamiento erasmista. Apuntes para una iconografía de género», en Tausiet; Amelang (Coords.): El Diablo, pp. 211-231; Paz Torres, Margarita: «Demonio y mujer: la marca de Satán y el combate contra él», Medievalia: Revista d'Estudis Medievals, 18:2, 2015, pp. 325-353.

68. Vida 25.14, p. 138.

69. Sobre las dificultades que tuvo Teresa con sus confesores, véanse Bilinkoff, Jodi: The Avila of Saint Teresa: Religious Reform in a Sixteenth-Century City, 2 ${ }^{\mathrm{a}}$ edición. Ithaca, 2014 
No obstante, el relato autobiográfico de Teresa sugiere que las desigualdades de género no pueden entenderse como algo estático. En ese relato cabe distinguir dos momentos clave: el de los hechos y el de su posterior interpretación al escribir sobre ellos. La subjetividad de Teresa en el momento de los hechos, cuando se veía amenazada por su propio miedo al demonio, y por las aseveraciones de Gaspar Daza y Francisco de Salcedo (dos hombres que tenían suficiente poder para amedrentarla), no puede entenderse como un ente cerrado y unitario, sino como resultado de la percepción que otros tenían de su situación como algo peligroso. El miedo tenía una función constitutiva: le daba forma a su yo, a la imagen que ella tenía de sí misma, o al menos a la imagen que presentaba en sus escritos.

$\mathrm{Al}$ reconstruir las experiencias más significativas de esos años de tribulaciones, de 1554 a 1560, la narración de Teresa transmite una imagen de sí misma que no parece discrepar de la imagen que tenían de ella Daza y Salcedo. Era el miedo con el que intentaban controlar la situación los teólogos el que se le imponía, como filtro que no le permitía ver nada más que peligros. Por lo que nos cuenta Teresa, la opinión de Daza y Salcedo de que estaba endemoniada («al parecer de entrambos era demonio») le produjo una angustia paralizadora («a mí me dio tanto temor y pena que no sabía qué me hacer: todo era llorar»), si bien se tranquilizó al leer en una epístola de San Pablo que Dios no consentía que los que le amaban fueran engañados por el demonio ${ }^{70}$. Siguiendo este testimonio autobiográfico, podemos comprobar cómo la subjetividad de Teresa no se construía sólo mediante sus relaciones con otras personas y con los objetos (según el modelo de subjetividad interactiva que proponían Ahmed y Labanyi), sino que también se fue construyendo mediante sus relaciones con los textos que leía.

Los libros, sin embargo, no bastaban para combatir la presión social en un contexto en el que se fomentaba el temor al demonio tanto en la predicación, como mediante la publicación de tratados que prevenían contra los engaños del demonio a las mujeres, entre los que cabe destacar el Tratado muy sotil y bien fundado de las supersticiones y hechizerias de Fray Martín de Castañega (1529) y la Reprobación de las supersticiones y hechicería de Pedro Ciruelo, que se publicó al menos once veces entre 1529 y $1556^{71}$. Castañega, por ejemplo, contribuyó a difundir la idea de que las mujeres eran más fácilmente engañadas por el demonio que los hombres por ser más débiles físicamente y más vulnerables mentalmente:

[1989], pp. 118-120; Bilinkoff: Related Lives: Confessors and their Female Penitents, 1450-1750. Ithaca, 2005, p. 77; Carrera: Teresa of Avila's Autobiography, pp. 119-143.

70. Vida 23.14-15, p. 130.

71. Se conservan ediciones de 1529, 1530, 1538, 1539, 1540, 1541, 1547 (dos impresiones), 1548, 1551 y 1556; véase Morgado García, Arturo: Demonios, magos y brujas en la España moderna. Cádiz, 1999, p. 9. 
Más son atormentadas en estos tiempos las mujeres, porque son más pusilánimes y de corazón más flaco, y de cerebro más húmedo, de complexión más astrosa; a las pasiones de ira y furia más sujetas; para sufrir tentaciones más flacas; para moverse a cada viento más ligeras.

Castañega recomendaba que se estuviera alerta no sólo contra los fingimientos de mujeres, a quienes tildaba de maliciosas, sino también contra los falsos exorcistas que colaboraban en sus engaños:

Por experiencia se ha visto que algunas personas, en especial mujeres, por su propia malicia, como alguna vez fingen que están ligadas, maleficiadas o hechizadas, así fingen que están espiritadas o endemoniadas por algunos descontentos que tienen de sus esposos o maridos, o por grandes amores carnales que tienen con alguno, o por terribles tentaciones de la carne, que el demonio enciende en ellas, y algunas veces los mismos conjuradores son partícipes de estos engaños; y esto se puede ver y conocer en su gesto, si lo tienen bueno y sano, y en los tiempos e intervalos claros y alegres que tienen [...] ni las crean ni se maravillen por los gestos que hacen cuando les hablan de ello, o las conjuran o santiguan o les hacen algún otro beneficio, porque la mujer que a ello se determina ligeramente hace gestos espantosos, y más que el demonio le da favor para ello [...] no se curen de ellas para darles audiencia, autoridad ni crédito, salvo con buenos consejos de religiosos y aprobados varones, y de buenas y honradas matronas, o con el conjuro del padre sobredicho ${ }^{72}$.

Teresa buscó la ayuda de jóvenes de la Sociedad de Jesús, del Colegio de San Gil, que acababa de fundarse en Ávila (en 1554), pero tardó años en convencer a los clérigos más influyentes de la ciudad de que iba por buen camino ${ }^{73}$. El primer jesuita que se prestó a hacerle de guía espiritual fuera del convento, Diego de Cetina, de 24 años, fue su confesor sólo dos meses; su partida la dejó «muy desconsolada y temerosa $»^{74}$. Su segundo confesor jesuita, Juan de Prádanos, de 27 años, al que consiguió acceder los dos años siguientes (1555-1556) hospedándose en casa de una pariente, la intentó ayudar animándola a que recitara el himno Veni, Creator con frecuencia. Tras pasar todo un día entregada a esa práctica, tuvo su primer arrebatamiento místico, en el que Dios le sugería que no tuviera conversación con hombres, sino con ángeles. Según escribiría seis años después, el escuchar esa voz le produjo «temor» pero la dejó sintiendo un «gran consuelo», y muy «animosa» ${ }^{75}$.

72. Castañega, Martín de: Tratado de las supersticiones y bechicerías, edición preparada por Agustín González de Amezúa. Madrid, 1946, pp. 139-148.

73. Para entender la precaria posición de los jesuitas en ese momento, véanse: O’Maille, John W.: The First Jesuits. Cambridge, Mass., 1993; Lozano Navarro, Julián José: La compañia de Jesús y el poder en la España de los Austrias. Madrid, 2005.

74. Vida 24.4, p. 132.

75. Vida 24.5-7, p. 133. 
Al ser trasladado Prádanos, en 1556, Teresa acudió a un tercer confesor jesuita, Baltasar Álvarez, de 25 años, que estuvo constantemente sujeto a críticas, amenazas y advertencias:

Supe que le decían que se guardase de mí, no le engañase el demonio con creerme algo de lo que le decía. Traíanle ejemplos de otras personas. Todo esto me fatigava a mí. Temía que no havía de haver con quién me confesar ${ }^{76}$.

El jesuita siguió escuchando sus confesiones durante seis años, a pesar de las críticas que recibió, y fue dándole ánimos y tranquilizándola:

que no ofendiese yo a Dios, ni saliese de lo que él me decía, que no huviese miedo me faltase; siempre me animava y sosegava. [...] Yo, como traía tanto miedo, obedecíale en todo, aunque imperfetamente ${ }^{77}$.

Álvarez confiaba en que Teresa no estaba endemoniada. Por otro lado, cabía la posibilidad de que sus visiones se debieran a causas naturales, como las que había señalado Ciruelo en su Reprobación casi treinta años atrás: "el sacerdote ante todas cosas procure de saber si aquel mal es demonio o si es otra dolencia alguna de coraçón o de celebro, etc, porque algunas veces parece demonio y no lo es ${ }^{78}$. Los años en que Teresa peor lo pasó coincidieron con el auge de la idea de que el demonio se hacía servir de los humores que facilitaban la formación de imágenes en el cerebro para producir visiones, como señalaba el gran teólogo dominico Domingo de Soto, en De iustitia et iure (1556):

Los demonios pueden ejercer su poder en aquellas fuerzas que a nosotros nos parecen milagrosas de tres maneras. Una, haciendo que aparezcan cosas que realmente no existen, y esto mediante la transmutación del órgano de la fantasía, del movimiento de las especies y de los humores humeantes de la cabeza, como ocurre en los que sueñan y en los frenéticos y privados del sentido, los cuales mediante este engaño de los sentidos ven en el aire muchas cosas que realmente no existen ${ }^{79}$.

El apoyo del joven Álvarez no bastaba para calmar los ánimos de los clérigos, que estaban convencidos de la necesidad de exorcizar a Teresa: «hartas afrentas y trabajos he pasado en decirlo, $y$ hartos temores y hartas persecuciones. Tan cierto

76. Vida 28.14 , p. 153.

77. Vida 28.15, p. 153.

78. Ciruelo, Pedro: Reprobación de las supersticiones y hechicerías. Madrid, 1912 [reimpreso Valladolid, 2005], p. 112.

79. Soto, Domingo de: De la justicia y del Derecho [1556]. Madrid, 1968, p. 765. Esta idea se difundiría en Europa en la segunda mitad del siglo XVI, sobre todo a partir de la publicación del tratado de Juan Wiero: Weyer, Johann: De Praestigiis Daemonum et Incantationibus ac Venificiis (De la ilusión de los demonios, encantamientos y venenos). Basilea, 1563. 
les parecía que tenía demonio que me querían conjurar algunas personas». Ella tenía que aguantar no sólo críticas y burlas, sino también las consecuencias del miedo al demonio de quienes la rodeaban: «de esto poco se me dava a mí; mas sentía cuando vía yo que temían los confesores de confesarme u cuando sabía les decían algo» ${ }^{80}$. Parece ser que el miedo de sus confesores al demonio dejó de afectarle tras su encuentro con el asceta franciscano Pedro de Alcántara, que le confirmó que sus experiencias estaban inspiradas por Dios ${ }^{81}$.

En muchos momentos en los que no tenía a nadie que le pudiera sacar de sus dudas, Teresa estaba tan asustada pensando si sus experiencias místicas eran engaños del diablo que no se atrevía ni a leer ni rezar:

Pues estándome sola, sin tener una persona con quien descansar, ni podía rezar ni leer, sino como persona espantada de tanta tribulación y temor de si me havía de engañar el demonio, toda alborotada y fatigada, sin saber qué hacer de mí. En esta aflicción me vi algunas y muchas veces, aunque no me parece ninguna en tanto estremo. Estuve así cuatro o cinco horas, que consuelo del cielo ni de la tierra no havía para mí, sino que me dejó el Señor padecer, temiendo mil peligros ${ }^{82}$.

Incluso en esos momentos, su interacción con historias que había leído, y de las que había oído hablar en los sermones, como el episodio del evangelio de Mateo (Mat. 8:26), le daba la confianza suficiente para combatir sus miedos:

Es así, cierto, que muchas veces me acordaba de cuando el Señor mandó a los vientos que estuviesen quedos, en la mar, cuando se levantó la tempestad y ansí decía yo: ¿Quién es éste que ansí le obedecen todas mis potencias, y da luz en tan gran oscuridad en un momento, y hace blando un corazón que parecía piedra, da agua de lágrimas suaves adonde parecía había de haber mucho tiempo sequedad?; ¿quién pone estos deseos?; ¿quién da este ánimo?; que me acaeció pensar: ¿de qué temo? ¿qué es esto? [...] Pues si este Señor es poderoso, como veo que lo es y sé que lo es, y que son sus esclavos los demonios -y de esto no hay que dudar, pues es fe-, siendo yo sierva de este Señor y Rey, ¿qué mal me pueden ellos hacer a mí? ¿Por qué no he yo de tener fortaleza para combatirme con todo el infierno?

El acordarse de ese episodio evangélico no sólo sirvió para transformar su forma de pensar, sino que también le llevó a un nuevo estado emocional marcado por la intersubjetividad. El proceso interactivo que le ayudó a no verse sola ante los demonios estuvo apoyado por objetos tan simbólicos como el crucifijo, que representaba al ser todopoderoso:

80. Vida 29.4 , p. 155 .

81. Vida 30.11, p. 161.

82. Vida 25.17, p. 138. 
Tomaba una cruz en la mano y parecía verdaderamente darme Dios ánimo, que yo me vi otra en un breve tiempo, que no temiera tomarme con ellos a brazos, que me parecía fácilmente con aquella cruz los venciera a todos. Y así dije: «ahora venid todos, que siendo sierva del Señor yo quiero ver qué me podéis hacer».

$\mathrm{Al}$ poner en práctica (enaction) sus creencias sobre el poder infinito de la cruz, no sólo dejó de temer a los demonios, sino que llegó a convencerse de que éstos le temían a ella:

Es sin duda que me parecía me havían miedo, porque yo quedé sosegada y tan sin temor de todos ellos, que se me quitaron todos los miedos que solía tener, hasta hoy. Porque, aunque algunas veces los veía, como diré después, no los he habido más casi miedo, antes me parecía ellos me le havían a mí. Quedóme un señorío contra ellos bien dado del Señor de todos, que no se me da más de ellos que de moscas. Parécenme tan covardes que, en viendo que los tienen en poco, no les queda fuerza.

No saben estos enemigos de hecho acometer, sino a quien ven que se les rinde, o cuando lo primite Dios para más bien de sus siervos que los tienten y atormenten ${ }^{83}$.

A partir de ese momento, que coincidió con su encuentro con Alcántara, empezó a entender las dificultades como pruebas y tentaciones del demonio, como las que había tenido Job (Job 2:6), y se dio cuenta de que lo importante era reconocer las tentaciones como tales: «y ansí querría avisar a vuestra merced para que, si por aquí le tentare, tenga alguna luz y lo conozca» ${ }^{84}$. En lugar de verse a sí misma como víctima irrecuperable de la posesión demoniaca, optó por ver los momentos de confusión como un juego pasajero de los demonios, permitido por Dios:

Y es ansí, que me ha acaecido parecerme que andan los demonios como jugando a la pelota con el alma, y ella que no es parte para librarse de su poder. No se puede decir lo que en este caso se padece. Ella anda a buscar reparo y primite Dios no le halle ${ }^{85}$.

Al narrar ese episodio difícil de su vida, reconoció que cuando había estado bajo la influencia del demonio había tenido que ser controlada para evitar que hiriera a otras monjas, física o verbalmente:

Tener, pues, conversación con nadie, es peor; porque un espíritu tan desgustado de ira pone el demonio, que parece a todos me querría comer, sin poder hacer más, y algo parece se hace en irme a la mano, $u$ hace el Señor en tener de su mano a quien

83. Vida 25.19-20, p. 139.

84. Vida 30.10 , p. 161

85. Vida 29.4, p. 155. 
ansí está, para que no diga ni haga contra sus prójimos cosa que los perjudique y en que ofenda a $\operatorname{Dios}^{86}$.

Teresa también describió una serie de experiencias que le turbaron («turbaciones interiores y secretas»), que ella explica como apariciones del demonio. En una ocasión, se le apareció «hacia el lado izquierdo» en forma de «abominable figura», amenazándole:

en especial miré la boca, porque me habló, que la tenía espantable. Parecía le salía una gran llama de el cuerpo, que estava toda clara, sin sombra. Díjome espantablemente que bien me havía librado de sus manos, mas que él me tornaría a ellas.

Aunque reaccionó con «gran temor», como era previsible, consiguió que la visión desapareciera momentáneamente santiguándose, y de forma definitiva echando agua bendita en esa dirección ${ }^{87}$. En otra ocasión sintió «terribles dolores y desasosiego interior y esterior» que le duraron cinco horas, y salió adelante pidiéndole a Dios paciencia. Al contarlo, no sólo explica que era cosa del demonio, sino que también afirma que ya en ese momento estaba convencida de la víctima ya no era ella, sino él: «quiso el Señor entendiese cómo era el demonio, porque vi cabe mí un negrillo muy abominable, regañando como desesperado de que adonde pretendía ganar perdía ${ }^{88}$. La rabia y desesperación que Teresa atribuía al demonio puede entenderse mejor a partir de la explicación que da Osuna en el Tercer Abecedario, al advertir que el demonio dará «guerra continua» a quienes consigan superarse moralmente porque no le gusta perder sus batallas:

Por eso tú, hermano, si has dejado el mundo y vencido algún vicio, piensa que has enojado más contra ti al demonio y le has dado causa que tenga especial odio y rencor contigo, el cual, aunque parezca que calla, no pienses que hace otra cosa sino armarse y hacer gente contra ti ${ }^{89}$.

Si bien Teresa estaba prevenida contra el demonio, la situación era muy diferente desde el punto de vista de las monjas que estaban con ella:

Yo, como le vi, reíme, y no hube miedo, porque había allí algunas conmigo que no se podían valer ni sabían qué remedio poner a tanto tormento, que eran grandes los golpes que me hacía dar sin poderme resistir, con cuerpo y cabeza y brazos. Y lo peor era el desasosiego interior, que de ninguna suerte podía tener sosiego.

86. Vida 30.13 , p. 162.

87. Vida 31.2, p. 165.

88. Vida 31.3-4, p. 165.

89. Tercer abecedario 7.2, en OSUNA: Tercer abecedario espiritual. Madrid, 1974, p. 219. 
Debía ser todo un espectáculo ver a Doña Teresa dando golpes a su alrededor con todo el cuerpo, con la cabeza y los brazos, a la vez que se reía. Desde el punto de vista de las monjas, la situación sólo tenía dos explicaciones: o estaba loca, o estaba endemoniada. Según su testimonio, consiguió mantener la cordura más allá de las apariencias, hasta el punto de hacer todo lo posible para evitar que la tuvieran por endemoniada: «no osaba pedir agua bendita por no las poner miedo y porque no entendiesen lo que era» ${ }^{90}$.

Al escribir sobre todos estos acontecimientos en su autobiografía, en 1562, Teresa ya no sólo no se dejaba amedrentar por los teólogos, sino que también se permitía aconsejarles. Si las opiniones de los teólogos de Avila estaban refrendadas no sólo por la autoridad de sus estudios sino también por el poder que les daban sus cargos eclesiásticos, Teresa apelaba ahora a la empatía de un teólogo más ilustre y de mayor influencia social, el dominico García de Toledo, para conseguir que se aceptara la autoridad de la experiencia:

Y es grande, cierto, el travajo que se pasa, y es menester tiento, en especial con mujeres, porque es mucha nuestra flaqueza y podría venir a mucho mal diciéndoles muy claro es demonio; sino mirarlo muy bien, y apartarlas de los peligros que puede haber, y avisarlas en secreto pongan mucho y le tengan ellos, que conviene.

Y en esto hablo como quien le cuesta harto trabajo no le tener algunas personas con quien he tratado mi oración, sino preguntando unos y otros, por bien me han hecho harto daño, que se han divulgado cosas que estuvieran bien secretas -pues no son para todos-, y parecía las publicaba yo. Creo sin culpa suya lo ha primitido el Señor para que yo padeciese. No digo que decían lo que tratava con ellos en confesión; mas, como eran personas a quien yo dava cuenta por mis temores para que me diesen luz, parecíame a mí havían de callar. Con todo, nunca osava callar cosa a personas semejantes.

Pues digo que se avise con mucha discreción, animándolas y aguardando tiempo, que el Señor las ayudará como ha hecho a mí; que si no, grandísimo daño me hiciera, sigún era temerosa y medrosa. Con el gran mal de corazón que tenía, espántome cómo no me hizo mucho mal ${ }^{91}$.

Teresa también criticó a los confesores que temían al demonio diciendo que ella les temía más que al demonio mismo:

Y ¡una higa para todos los demonios!, que ellos me temerán a mí. No entiendo estos miedos: ¡demonio! ¡demonio!, adonde podemos decir: ¡Dios ¡Dios!, y hacerle temblar. Sí, que ya sabemos que no se puede menear si el Señor no lo primite.

90. Vida 31.4, pp. 165-166.

91. Vida 23.13, pp. 129-130. 
¿Qué es esto? Es sin duda que tengo ya más miedo a los que tan grande le tienen a el demonio que a él mesmo; porque él no me puede hacer nada, y estotros, en especial si son confesores, inquietan mucho, y he pasado algunos años de tan gran travajo, que ahora me espanto cómo lo he podido sufrir. ¡Bendito sea el Señor que tan de veras me ha ayudado! ${ }^{92}$

A partir de esta lectura intersubjetiva de este texto autobiográfico, podemos argumentar que si bien el miedo puede servir para generar, legitimar y aceptar la desigualdad social, como señalaba Ahmed en términos generales, el hablar de la experiencia de miedo puede servir para eliminar o reducir los miedos de otros, y compensar las situaciones de desigualdad, o al menos aliviar los sentimientos de inseguridad que suelen ir asociados a ésta. Ahora bien, no hay que olvidar que tanto los discursos del miedo como los discursos que intentan reducirlo están sometidos a relaciones de poder, que suelen afectar a su difusión. Tampoco hay que olvidar que tanto Teresa como sus confesores podían ser juzgados en cualquier momento por la Inquisición, y que eran plenamente conscientes de ello: «e iban a mí con mucho miedo a decirme que andaban los tiempos recios y que podría ser me levantasen algo y fueran a los inquisidores» ${ }^{93}$. Según su propio testimonio, ella intentaba contrarrestar el miedo que todos parecían tener demostrando alegría y despreocupación, hasta el punto de echarse a reír:

A mí me cayó esto en gracia y me hizo reír, porque en este caso jamás yo temí, que sabía bien de mí que en cosa de fe contra la menor cerimonia de la Iglesia que alguien viese yo iva, por ella u por cualquier verdad de la Sagrada Escritura me pornía yo a morir mil muertes; y dije que de eso no temiesen ${ }^{94}$.

Lo que no nos cuenta aquí son los trámites que hizo para conseguir la aprobación del inquisidor Francisco Soto de Salazar, con quien se entrevistó, por iniciativa propia en 1562, y quien al parecer le recomendó que escribiera su autobiografía espiritual, y se la mandara al maestro Juan de Ávila. ${ }^{95}$ Tardó seis años en conseguir hacerle llegar su libro, por mediación de una aristócrata de alta alcurnia, doña

92. Vida 25.22, p. 140. Para un análisis de las referencias al demonio en Las moradas, que Teresa escribiría en 1577, véase: Greiner, Frank: ««Hacer al demonio guerra con sus mismas maldades». Santa Teresa y la imaginación», en Borrego; Losada: (Coords.): Cinco Siglos de Teresa, pp. 51-65.

93. Vida 33.5, p. 179.

94. Vida 33.5, p. 179.

95. Esto lo cuenta en una relación que escribe para los inquisidores de Sevilla en 1576: «Díjole, como la vio tan fatigada, que lo escribiese todo y toda su vida, sin dejar nada, al Maestro Ávila, que era hombre que entendía mucho de oración, y que con lo que escribiese se sosegase. Ella lo hizo así y escribió sus pecados y vida»; Cuenta de Conciencia 57.8, en Teresa de Jesús: Obras, pp. 617-624 (619). 
Luisa de la Cerda ${ }^{96}$. Al final, a pesar de la aprobación del santo maestro, pocas personas pudieron leer la autobiografía de Teresa durante su vida. El manuscrito original permaneció catorce años en las arcas de la Inquisición, tras haber sido denunciado por la Princesa de Éboli al Tribunal Inquisitorial de Valladolid por contener visiones en $1574^{97}$. El libro no se quemó, y a su autora no se le condenó, gracias al informe favorable que escribió para la Inquisición el teólogo dominico Domingo Báñez al año siguiente:

Sólo una cossa hay en este libro en que poder reparar, y con razón, basta examinarla muy bien: $\mathrm{y}$ es que tiene muchas revelaciones y visiones, las cuales siempre son mucho de temer, especialmente en mujeres, que son más fáciles en creer que son de Dios. [...] Mas no por eso hemos de hacer regla general de que todas las revelaciones y visiones son del demonio. [...] Y tampoco menosprecio sus revelaciones y visiones y arrobamientos, antes sospecho que podían ser de Dios como en otros santos lo fueron. Mas en este casso siempre es más seguro quedar con miedo y recato; porque en habiendo seguridad, tiene lugar el diablo de hazer sus tiros, y lo que antes era quizá de Dios se trocará y será del demonio ${ }^{98}$.

La recomendación de Báñez, según su declaración durante el proceso de beatificación de Teresa en 1590, fue que se evitara que la autobiografía de Teresa se difundiera, en copias manuscritas o como texto impreso, hasta saber si realmente era santa: «veremos en qué para esta mujer» ${ }^{99}$. En el libro de las Fundaciones y en cartas que escribiría entre 1576 y 1580 a la priora de Sevilla, María de San José, la misma Teresa sugeriría que el demonio podía estar detrás de las visiones y revelaciones que las monjas creían de origen divino ${ }^{100}$.

La autobiografía se publicó junto con otras obras de Teresa, en 1588, seis años después de su muerte, cuando se había exhumado su cuerpo varias veces y se había comprobado que permanecía incorrupto. Ya se le tenía por santa. A partir de ese

96. Véanse las cartas de Teresa a Doña Luisa de la Cerda del 27 de mayo y del 2 de noviembre de 1568; en Teresa de Jesús: Obras, pp. 874 y 881.

97. Sobre los encuentros de Teresa con la Inquisición, véase Llamas Martinez: Santa Teresa de Jesús y la Inquisición española. Madrid, 1972.

98 «Censura del P. Domingo Báñez en el autógrafo de la Vida», en Teresa de Jesús: Obras, pp. 230-232.

99. Santa Teresa, Silverio de (Ed.): Procesos de beatificación y canonización de Santa Teresa de Jesús, 3 vols. Burgos, 1935, I, p. 10.

100. Weber, Alison: «Saint Teresa, Demonologist», en Cruz, Anne J.; Perry, Mary Elizabeth (Coords.): Culture and Control in Counter-Reformation Spain. Minneapolis, 1992, pp. 171-195; Weber: «Spiritual Administration: Gender and Discernment in the Carmelite Reform», Sixteenth Century Journal, 31:1, 2000, pp. 127-150; Carrera.: «Mental Affliction, Deviance and Culpability in Sixteenth-Century Spain: Beyond Binary Categories», eHumanista, 36, 2017, pp. 23-41. 
momento, ya no se vería su experiencia como la de una mujer entre otras, de la que se podía aprender. Se vería su escritura como producto de la inspiración divina, lo que haría que no se tuviera en cuenta hasta qué punto su subjetividad había sido producto de sus lecturas y su interacción con su familia, amigos, monjas, frailes y teólogos, de los que aprendió a tener miedo al infierno y al demonio.

El 3 de octubre de 1615, como parte de las celebraciones que se hicieron por toda España y el sur de Francia para celebrar la beatificación de Teresa, que se confirmaría al día siguiente, se hicieron una serie de sermones, en los que se presentó a Teresa como una «flaca mujer», que había sido más efectiva en la lucha contra el demonio que los hombres valientes y los grandes letrados. Por ejemplo, el jesuita Cipriano de Aguayo, que predicó ese día en el convento de carmelitas descalzas de Toledo, afirmaba:

pues por mano de una flaca muger, para muestra de su potencia alcançó gloriosísimas vitorias, mayores harto que las que alcançó por mano de Débora, porque quando el demonio parece que en este miserable siglo nuestro triunfa en la muchedumbre de los infieles, y en la perfidia de tantos pueblos Hereges que hazen sus partes, en el mal viuir de tantos malos y pecadores Católicos; para hazer burla deste común enemigo, quiso Dios oponerle, no un hombre valiente, no un gran Letrado y Doctor $[\ldots]$ sino una flaca muger que le desafíe y leuante contra él vandera ${ }^{101}$.

En otro sermón, ante el público congregado en el convento de Carmelitas Descalzas de Madrid, el dominico Domingo Daza invocaba a Teresa como la elegida por Dios en la batalla contra el vicio: «dexando a los varones santos y doctos os escogió a vos para hazer guerra al infierno, degollar los vicios, y reformar el siglo» ${ }^{102}$. Este tipo de apelación en segunda persona es el volvemos a encontrar casi cuatro siglos después en la lectura intersubjetiva que ofrecería Julia Kristeva en Teresa, amor mío:

Le saludo, Teresa, mujer sin fronteras, física erótica histérica epiléptica, que se hace verbo que se encarna, que se deshace en sí misma fuera de sí, torrentes de imágenes sin cuadros, tumultos de palabras, cascadas de florecimientos convertidas en lenguas a la escucha de quien de qué, escucha el tiempo tallado, el tímpano garganta grito escrito, noche y luz, demasiado cuerpo y sin cuerpo [...]. El está en ella, ella en él, presentido sentido engullido, sensación sin percepción, dardo

101. Jesús María, José de (Ed.): Sermones predicados en la Beatificacion de la Beata Madre Teresa de Iesus Virgen, fundadora de la Reforma de los Descalços de Nuestra Señora del Carmen. Madrid, 1615, fol. 118v; citado en Rowe, Erin Kathleen: «The Spanish Minerva: Imagining Teresa of Avila as Patron Saint in Seventeenth-Century Spain», The Catholic Historical Review, 92:4, 2006, pp. 574-596 (580).

102. Véase Jesús María, Sermones, fol. 56r. 
o cristal, transperforado o transparente, esa es la cuestión, transverberación más bien e incluso inundación, la Madre es la más viril de los monjes, la más hábil líder de almas, un gemelo de Cristo, ella es Él, Él es ella, la Verdad soy yo, él está en el fondo íntimo de mi ser, yo Teresa, paranoide exitosa, Dios soy yo ¡y qué! ¿qué pasa? un festín para todos ${ }^{103}$.

Kristeva atribuía esa apelación a Sylvia Leclerc, una psicoterapeuta ficticia con quien se identificaba en ese largo texto de 2008. Nueve años más tarde volvería a escribir sobre Teresa para una colección de estudios teológicos:

500 años antes de nuestra época ella elucidó esa extraña experiencia que, situada en los márgenes del significado y de la sensación, es a la vez cuerpo y alma: los secretos de la escritura. En esos extremos, Teresa es nuestra contemporánea ${ }^{104}$.

Tenemos aquí un ejemplo del segundo tipo de lector/a, no familiarizado/a con el contexto histórico de Teresa, a quien no interesan los miedos que ésta describe en su autobiografía, quizá porque éstos no tienen sentido si no se comparten las creencias que los inspiran, como la idea del premio o condena eterna, o la noción del demonio como ser agente que puede ser alejado con un exorcismo o con agua bendita. El ver a Teresa como «nuestra contemporánea», como la ve Kristeva, supone alejar su subjetividad de las ideas, las prácticas emocionales y las personas que marcaron sus experiencias, y crear una nueva intersubjetividad, que la hace enlazar con ideas y prácticas emocionales del siglo XXI. La otra opción, que hemos intentado mostrar en este trabajo es la de respetar la alteridad de textos y contextos ideológicos del pasado.

\section{CONCLUSIONES}

Al hilo de la lectura de la autobiografía de Teresa, hemos podido comprobar que para entender las ideas e ideologías que dieron forma y sentido a las emociones en la historia, no es necesario que compartamos esas ideas. Podemos entender el miedo al infierno, al demonio y a los confesores sin sentir esos miedos. Sólo basta saber pasar del «aquí» y «ahora» de los discursos que dan forma a nuestra propia subjetividad, al «allí» $\mathrm{y}$ «entonces» de lo que «hacían» los discursos del

103. Kristeva, Julia: Thérèse mon amour. París, 2008, pp. 40-41, mi traducción [véase la reciente traducción: Teresa, amor mío, trad. A. Rodríguez. Barcelona, 2015].

104. Kristeva: «The Passion According to Teresa of Avila», en Tyler, Peter; Howells, Edward (Coords.): Teresa of Avila: Mystical Theology and Spirituality in the Carmelite Tradition. Nueva York, 2016 (edición electrónica sin paginar): «500 years before our time she has elucidated that strange experience which is at the boundaries of meaning and sensation, body and soul together: the secrets of writing. At these extremities, Teresa is our contemporary». 
pasado. Como hemos visto, los textos devocionales no sólo intentaban provocar miedo, sino también dar esperanza y seguridad a quienes se propusieran cambiar de comportamiento, imitando el modelo de Cristo y de los santos. Sin embargo, los textos se limitaban a inspirar y prescribir prácticas ascéticas y de oración, cuyo éxito dependía en gran medida del grado en que se involucraran sus lectores sensorial y emocionalmente. A la vez, estas prácticas daban lugar a experiencias imprevistas, y a veces sospechosas, que estaban sometidas al control de quienes tenían el suficiente poder y la necesaria autoridad para hacer valer sus opiniones. El miedo y la confianza no se construían sólo mediante discursos, sino también mediante la capacidad de los individuos de interpretar, dar vida, o negar esos discursos.

Una de las dos conclusiones principales que cabe extraer de la lectura de la autobiografía de Teresa es que su miedo al infierno y su miedo al demonio pueden entenderse como miedos «intersubjetivos», porque estaban basados en las opiniones que otros tenían sobre ella. En ese sentido, hemos visto cómo las desigualdades sociales y las expectativas sobre diferencias de género podían tener como efecto que una mujer se viera a sí misma como «temerosa», cuando eran los hombres quienes proyectaban sus miedos sobre ellas. Quizá los teólogos temían al demonio tanto o más que las mujeres a quienes ellos tenían por endemoniadas, pero al señalarlas con el dedo, estaban desplazando hacia ellas sus miedos y los miedos de otros.

La segunda conclusión es que, si bien las desigualdades de género no tienen por qué entenderse como algo estático en el ámbito micro-social de las subjetividades individuales, éstas forman parte de un amplio marco socio-cultural, en el que los cambios han sido mucho más lentos. En el plano individual, Teresa pasó de ser víctima del miedo al demonio a utilizar el relato de su vida para intentar eliminar los miedos excesivos de sus confesores. Parece ser que su escritura tuvo cierto efecto en alguno de sus destinatarios, que pasaron a confiar en ella y a apoyar sus planes de reforma. Sin embargo, no consiguió eliminar el miedo colectivo a las mujeres. Con los discursos textuales y visuales que se superpusieron a la autobiografía de Teresa, como los relatos hagiográficos del Jesuita Francisco de Ribera en 1590 o los grabados en los que se la representaba sola con los demonios, se difundió la imagen de Teresa como una mujer excepcional y a la vez modélica ${ }^{105}$.

105. Véase por ejemplo el duodécimo de los grabados de Collaert y Galle en Vita B. Virginis. Véanse también De La Croix, Jean: "L'Iconographie de Thérèse de Jesus», Ephemerides Carmeliticae, 21, 1970, 219-260; Berbara, Maria: ««Esta pena tan sabrosa»: Teresa of Avila and the Figurative Arts», en Dijkhuizen, Jan Frans van; Enenkel, Karl A. E.: The Sense of Suffering: Constructions of Physical Pain in Early Modern Culture. Leiden/Boston, 2009, pp. 267-297; Pinilla: «Dos «vidas gráficas» de Santa Teresa de Jesús: Amberes 1613 y Roma 1655», Boletín del Seminario de Estudios de Arte y Arqueología. Arte, 79, 2013, pp. 183-202; Moreno Cuadro, 
Las representaciones hagiográficas en tercera persona y las ilustraciones que solían acompañarlas, sirvieron para seguir promoviendo la idea (que ella criticó en su autobiografía) de que no había razones para dejar de temer las visiones de las mujeres y que, por tanto, lo mejor que podía hacerse para controlar al demonio, o más bien controlar el miedo al demonio, era mortificar el cuerpo.

En definitiva, si queremos entender la función del miedo y otras emociones en la historia, no podemos pensar en ellas ni como experiencias subjetivas, situadas dentro de los individuos, ni como construcciones discursivas sin agencia. Para entender las emociones como prácticas sociales e intersubjetivas, debemos conocer más de cerca la historia de los valores, creencias e interpretaciones conflictivas que han prevalecido en los contextos en los que se han fomentado esas prácticas relacionales, y las transgresiones y experiencias contradictorias de los individuos y grupos que les han dado vida, cambiando su forma de entenderse a sí mismos, $\mathrm{y}$ de entender lo que sienten, al involucrarse en ellas.

\section{BIBLIOGRAFÍA}

Ahlgren, Gillian: Teresa of Avila and the Politics of Sanctity. Ithaca, 1996.

Ahmed, Sara: The Cultural Politics of Emotion. Nueva York, 2004 [La politica cultural de las emociones, trad. C. Olivares. México, D. F., 2015].

Alabrús, Rosa María y García Cárcel, Ricardo: Teresa de Jesús: La construcción de la santidad. Madrid, 2015.

Barclay, Katie: Love, Intimacy and Power: Marriage and Patriarchy in Scotland, 16501850. Manchester, 2011.

Berbara, Maria: ««Esta pena tan sabrosa»: Teresa of Avila and the Figurative Arts», en Dijkhuizen, Jan Frans van; Enenkel, Karl A. E.: The Sense of Suffering: Constructions of Physical Pain in Early Modern Culture., Leiden/Boston, 2009, pp. 267-297.

Bilinkoff, Jodi: Related Lives: Confessors and their Female Penitents, 1450-1750. Ithaca, 2005.

Bilinkoff, Jodi: The Avila of Saint Teresa: Religious Reform in a Sixteenth-Century City, $2^{a}$ edición. Ithaca, 2014 [1989].

Bolufer Peruga, Mónica (coord.): «Del uso de las pasiones: la civilización y sus sombras». Historia Social, 81, 2015.

Boquet, Damien; Nagy, Piroska (Coords.): Politiques des émotions au Moyen Âge. Florencia, 2010.

Boquet, Damien; Nagy, Piroska (Coords.): Sensible Moyen Âge. París, 2015.

Bound Alberti, Fay (Coord.): Medicine, Emotion and Disease, 1700-1950. Basingstoke, 2006.

Fernando: «Iconografía de los testigos de los procesos teresianos. A propósito de Adrian Collaert y la escenografía de la Capilla Cornaro», Archivo Español de Arte, 345, 2014, pp. 29-44.

Ediciones Universidad de Salamanca / 요 Stud. his., H. ${ }^{a}$ mod., 40, n. 2 (2018), pp. 63-111 
ELENA CARRERA

EL MIEDO INTERSUBJETIVO EN LA AUTOBIOGRAFÍA DE TERESA DE ÁVILA

Bound Alberti, Fay: Matters of the Hearth. History, Medicine, and Emotion. Nueva York/ Oxford, 2010.

Bourke, Joanna: «Fear and Anxiety: Writing about Emotion in Modern History», History Workshop Journal, 55:1, 2003, pp. 111-133.

Braddick, Michael J.; Innes, Joanna (Coords.): Suffering and Happiness in Early Modern England. Oxford, 2017.

Braudel, Fernand: Las ambiciones de la historia, edición preparada por Roselyne de Ayala y Paule Braudel, trad. M. J. Furió. Barcelona, 2002

Broomhall, Susan (Coord.): Authority, Gender and Emotions in Late Medieval and Early Modern England. Houndmills, 2015.

Broomhall, Susan (Coord.): Early Modern Emotions: An Introduction. Londres/Nueva York, 2017.

Broomhall, Susan (Coord.): Gender and Emotions in Medieval an Early Modern Europe: Destroying Order, Structuring Disorder. Farnham, 2015.

Callado Estela, Emilio (Coord.): Viviendo sin vivir en mi: Estudios en torno a Teresa de Jesús en el V Centenario de su nacimiento. Madrid, 2016

Camporesi, Piero: The Fear of Hell: Images of Damnation and Salvation in Early Modern Europe, trad. L. Byatt. Oxford, 1990 [orig. 1987].

Candau Chacón, María Luisa (Coord.): Las mujeres y las emociones en Europa y América: siglos XVII-XIX. Santander, 2016.

Carrera, Elena: «Writing Rearguard Action, Fighting Ideological Selves: Teresa of Avila’s Reinterpretation of Gender Stereotypes in Camino de perfección», Bulletin of Hispanic Studies, 79:3, 2002, pp. 299-308.

Carrera, Elena: Teresa of Avila's Autobiography: Authority, Power and the Self in MidSixteenth-Century Spain. Oxford, 2005.

Carrera, Elena: «The Emotions in Sixteenth-Century Spanish Spirituality», Journal of Religious History, 31:3, 2007, pp. 235-252.

Carrera, Elena (Coord.): Emotions and Health, 1200-1700. Leiden/Boston, 2013.

Carrera, Elena: «El miedo y la empatía en la escritura epistolar de Teresa de Jesús», en Borrego, Esther; Losada, José Manuel (Coords.): Cinco Siglos de Teresa: La proyección de la vida y los escritos de Santa Teresa de Jesús. Madrid, 2016, pp. 27-48.

Carrera, Elena: «Mental Affliction, Deviance and Culpability in Sixteenth-Century Spain: Beyond Binary Categories», eHumanista, 36, 2017, pp. 23-41.

Carrera, Elena: «From Fear to Courage: The Testimonies of Teresa of Avila and her Early Hagiographers», en O’Reilly, Terence; Thompson, Colin; Twomey, Lesley (Coords.): Saint Teresa of Avila: Her Writings and Life. Oxford, 2018, pp. 150-166.

Castañega, Martín de: Tratado de las supersticiones y bechicerías, edición preparada por Agustín González de Amezúa. Madrid, 1946.

Ciruelo, Pedro: Reprobación de las supersticiones y bechicerías. Madrid, 1912 [reimpreso Valladolid, 2005]. 
Courcelles, Dominique de: «La pensée de l'enfer dans le Libro de la vida de Thérèse d'Avila», en Duviols, Jean Paul; Moliné-Bertrand, Annie (Coords.): Enfers et damnations dans le monde hispanique et hispano-américain. París, 1996, pp. 231-245.

Chinchilla Pawling, Perla: «Predicación y miedo», en Gonzalbo Aizpuru, Pilar; Staples, Anne; Torres Septién, Valentina (Coords.): Una historia de los usos del miedo, México, D.F., 2009, pp. 203-221.

Dalmases, Cándido de: «Santa Teresa y los Jesuitas. Precisando fechas y datos», Archivum Historicum Societatis Jesu, 35, 1966, pp. 347-378.

De La Croix, Jean: «L'Iconographie de Thérèse de Jesus», Ephemerides Carmeliticae, 21, 1970, 219-260.

Delumeau, Jean: Le Péché et la peur: La culpabilisation en Occident (xiïi-xviiie siècles). París, 1983.

Delumeau, Jean: El miedo en Occidente (siglos XIV-XVIII): una ciudad sitiada, trad. M. Armiño. Madrid, 1989 [Orig. 1978].

Delumeau, Jean: Rassurer et Protéger. Le sentiment de sécurité dans l'Occident d'autrefois. París, Fayart, 1989.

Delumeau, Jean: «Le démon, l'enfer et les peurs de la Renaissance», Le Monde des Religions, Marzo-abril 2005, pp. 38-39.

Di Paolo, Ezequiel; De Jaegher, Hanne: «The Interactive Brain Hypothesis», Frontiers in Human Neuroscience, 6:163, 2012, pp. 1-16.

Díaz Freire, José Javier (Coord.): «Emociones e historia», monográfico en Ayer, 98, 2015.

Dunant, Sarah; Porter, Roy: The Age of Anxiety. Londres, 1996.

Duviols, Jean Paul ; Moliné-Bertrand, Annie (Coords.): Enfers et damnations dans le monde hispanique et hispano-américain. París, 1996.

Egido, Teófanes.: «Santa Teresa y sus cartas, historia de los sentimientos», Hispania Sacra, 67, 2015, pp. 401-428.

Foka, Anna; Liliequist, Jonas: Laughter, Humor, and the (Un)Making of Gender: Historical and Cultural Perspectives. Nueva York, 2015.

Forestié, Edouard: La Grande Peur. Montauban, 1911.

Foucault, Michel: «El Sujeto y el Poder», en Dreyfus, Hubert L.; Rabinow, Paul (Eds.): Más allá del Estructuralismo y la Hermenéutica, trad. C. de Iturbe. México, DF, 1988 [orig. 1982].

Foucault, Michel: Tecnologías del yo y otros textos afines, trad. M. Allendesalazar, Barcelona, 1990 [orig. 1988].

Foucault, Michel: Vigilar y castigar. México, D.F., 1990 [orig. 1975].

Foucault, Michel: «La ética del cuidado de si como práctica de la libertad», trad. D. Fonti, en Nombres. Revista de Filosofía, 10:15, 2000, pp. 257-280 [orig. 1994].

Foucault, Michel: La hermenéutica del sujeto. Curso en el Collège de France, 1981-1982. Buenos Aires, 2009 [orig. 2001].

Fumagalli, Vito: Landscapes of Fear: Perceptions of Nature and the City in the Middle Ages, trad. S. Mitchell. Stanford/Londres, 1994 [orig. 1976].

Ediciones Universidad de Salamanca / @®@ Stud. his., H. ${ }^{a}$ mod., 40, n. 2 (2018), pp. 63-111 
Gammerl, Benno: «Emotional Styles - Concepts and Challenges», Rethinking History: The Journal of Theory and Practice, 16:2, 2012, pp. 161-175.

García Cárcel, Ricardo: «Los tiempos recios de Teresa de Jesús», en Callado Estela, Emilio (Coord.): Viviendo sin vivir en mi: Estudios en torno a Teresa de Jesús en el $V$ Centenario de su nacimiento. Madrid, 2016, pp. 13-41.

García Rubio, Francisco: «La función retórico-jurídica del demonio en el Libro de la vida de Teresa de Jesús», eHumanista, 17, 2011, pp. 185-204.

Gonzalbo Aizpuru, Pilar; Staples, Anne; Torres Septién, Valentina (Coords.): Una historia de los usos del miedo, México, D.F., 2009.

González Candela, Francisco Javier: «El contraste místico del bien y el mal: la presencia del demonio en la Vida de santa Teresa de Jesús», en Mata Induráin, Carlos; Zúñiga Lacruz, Ana (Coords.): «Venia docendi». Actas del IV Congreso Internacional Jóvenes Investigadores Siglo de Oro (JISO 2014). Pamplona, 2015, pp. 85-94.

Gouk, Penelope; Hills, Helen (Coords.): Representing Emotions: New Connections in the Histories of Art, Music and Medicine, Aldershot, 2005.

Granada, Luis: Libro de la oración y meditación. Amberes, 1559.

Greiner, Frank: «Hacer al demonio guerra con sus mismas maldades». Santa Teresa y la imaginación», en Borrego, Esther; Losada, José Manuel: Cinco Siglos de Teresa: La proyección de la vida y los escritos de Santa Teresa de Jesús. Madrid, 2016, pp. 51-65.

Guillaume-Alonso, Araceli: «Enfer et damnation dans la pastorale jésuite au XVIe siècle», en Duviols, Jean Paul; Moliné-Bertrand, Annie (Coords.): Enfers et damnations dans le monde hispanique et hispano-américain. París, 1996, pp. 247-261.

Hamilton, Alastair: Heresy and Mysticism in Sixteenth-Century Spain. Toronto, 1992.

Hamilton, Alastair: «The alumbrados: Dejamiento and its Practitioners», en Kallendorf, Hilary (Coord.): A New Companion to Hispanic Mysticism. Leiden/Boston, 2010.

Hochschild, Arlie: «Emotion work, feeling rules, and social structure», American Journal of Sociology, 85, 1979, pp. 551-575.

Hochschild, Arlie: The Managed Heart: Commercialization of Human Feeling. Berkeley, 1983.

Hoffman, Martin L.: «Empathy and prosocial behavior», en Feldman Barrett, Lisa; Lewis, Michael; Haviland-Jones, Jeannette M. (Coords.): Handbook of Emotions, tercera edición. Nueva York/Londres, 2010, pp. 440-455.

Jarzebowski, Claudia; Safley, Thomas M. (Coords.): Childhood and Emotion across Cultures 1450-1800. Londres, 2014.

Jesús María, José de (Ed.): Sermones predicados en la Beatificacion de la Beata Madre Teresa de Iesus Virgen, fundadora de la Reforma de los Descalços de Nuestra Señora del Carmen. Madrid, 1615.

Kahn, Victoria; Saccamano, Neil; Coli, Daniela: Politics and the Passions, 1500-1850. Princeton, 2006.

Karant-Nunn, Susan: The Reformation of Feeling: Shaping the Religious Emotions in Early Modern Germany. Nueva York/Oxford, 2010. 
Kristeva, Julia: Thérèse mon amour. París, 2008 [Teresa, amor mio, trad. A. Rodríguez. Barcelona, 2015].

Kristeva, Julia: «The Passion According to Teresa of Avila», en Tyler, Peter; Howells, Edward (Coords.): Teresa of Avila: Mystical Theology and Spirituality in the Carmelite Tradition. Nueva York, 2016.

Kuijpers, Erika; van der Haven, Cornelis (Coords.): Battlefield Emotions 1500-1850: Practices, Experience, Imagination, Basingstoke, 2016.

Labany, Jo: «Doing Things: Emotion, Affect, and Materiality», Journal of Spanish Cultural Studies, 11: 3-4, 2010, pp. 223-233.

Lansing, Carol: Passion and Order: Restraint of Grief in the Medieval Italian Communes. Ithaca, 2008.

Lefebvre, Georges: La Grande peur de 1789. París, 1932.

Liliequist, Jonas: A History of Emotions, 1200-1800. Londres, 2012.

Lisón Tolosana, Carmelo: Demonios y exorcismos de los Siglos de Oro. La España mental I. Madrid, 1990.

Llamas Martinez, Enrique: «Demonismo y hechicería en El libro de la Vida», en Barrientos, Alberto (Coord.): Introducción a la lectura de Santa Teresa. Madrid, 2002, pp. 210-240.

Llamas Martinez, Enrique: Santa Teresa de Jesús y la Inquisición española. Madrid, 1972.

Losin, Elizabeth A. R.; Dapretto, Mirella; Iacoboni, Marco: «Culture in the Mind's Eye: How Anthropology and Neuroscience Can Inform a Model of the Neural Substrate for Cultural Imitative Learning», Progress in Brain Research, 178, 2009, pp. 175-190.

Loyola, Ignacio de: Obras completas de San Ignacio de Loyola, $3^{\text {a }}$ edición, preparada por Ignacio Iparraguirre y Cándido Dalmases. Madrid, 1977.

Lozano Navarro, Julián José: La compañia de Jesús y el poder en la España de los Austrias. Madrid, 2005.

Ludolfo de Sajonia: Vita Christi cartuxano romançado por fray Ambrosio [Montesino]: la quarta parte. Alcalá de Henares, 1503.

Lutz, Caterine A.: «Feminist Emotions», en Mageo, Jeannette Marie (Coord.): Power and the Self. Cambridge, 2002, pp. 194-215

MacDonald, Michael: Mystical Bedlam: Madness, Anxiety, and Healing in SeventeenthCentury England. Cambridge, 1981.

MacDonald, Michael: «The Fearefull Estate of Francis Spira: Narrative, Identity, and Emotion in Early Modern England», Journal of British Studies, 31:1, 1992, pp. 32-61.

Mackay, Angus; Wood, Richard: «Mujeres diabólicas», en Graña Cid, María del Mar; Muñoz Fernández, Ángela (Coords.): Religiosidad femenina: expectativas y realidades (ss. VII-XVIII). Madrid, 1991, pp. 187-196.

Márquez, Antonio: Los Alumbrados. Orígenes y filosofía, 1525-1559. Madrid, 1972.

Martínez-Burgos García, Palma: «Lo diabólico y lo femenino en el pensamiento erasmista. Apuntes para una iconografía de género», en Tausiet, María; Amelang, James S. (Coords.): El Diablo en la Edad Moderna. Madrid, 2004, pp. 211-231.

Moncó Rebollo, Beatriz: Mujer y demonio: una pareja barroca (treinta monjas endemoniadas en un convento). Madrid, 1989. 
Moncó Rebollo, Beatriz: «Demonios y mujeres: historia de una transgresión», en Tausiet, María; Amelang, James S. (Coords.): El Diablo en la Edad Moderna. Madrid, 2004, 187-210.

Moncy, Agnes: «Santa Teresa y sus demonios», Papeles de Son Armadans, 36:107, 1965, pp. 149-166.

Morales Zaragoza, María Luisa: «Lo pavoroso en el Libro de la vida de Santa Teresa de Jesús», en Díez de Velasco Abellán, Francisco (Coord.): Miedo y religión. Madrid, 2002, pp. 257-264.

Moreno Cuadro, Fernando: «Iconografía de los testigos de los procesos teresianos. A propósito de Adrian Collaert y la escenografía de la Capilla Cornaro», Archivo Español de Arte, 345, 2014, pp. 29-44.

Morgado García, Arturo: Demonios, magos y brujas en la España moderna. Cádiz, 1999. Moscoso, Javier: «La historia de las emociones: ¿de qué es historia?», Vínculos de Historia, 4, 2015, pp. 15-27.

Mujica, Barbara: Teresa of Avila: Lettered Woman. Nashville, 2009.

Nagy, Piroska ; Boquet, Damien (Coords.): Le Sujet des émotions au moyen âge. París, 2009.

Naphy, William G.; Roberts, Penny: Fear in Early Modern Society. Manchester, 1997.

Nava Sánchez, Alfredo: «Es por meter miedo a los hombres: el miedo al infierno en el siglo XVI novohispano», en Gonzalbo Aizpuru, Pilar; Staples, Anne; Torres Septién, Valentina (Coords.): Una historia de los usos del miedo, México, D.F., 2009, pp. 185-202.

Nicolás, Antonio T. de: Powers of Imagining. Ignatius de Loloya: A Philosophical Hermeneutic of Imagining through the Collected Works of Ignatius of Loyola. Albany, NY, 1986.

O’Maille, John W.: The First Jesuits. Cambridge, Mass., 1993.

Osuna, Francisco de: Tercer abecedario espiritual. Madrid, 1974.

Osuna, Francisco de: Segunda parte del libro llamado abecedario spiritual. Sevilla, 1530.

Pascua Sánchez, María José de la: Mujeres solas: historias de amor y de abandono en el mundo hispánico. Málaga, 1998.

Pascua Sánchez, María José de la; García-Doncel Hernández, María del Rosario; Espigado Tocino, Gloria (Coords.): Mujer y deseo. Representaciones y prácticas de vida. Cádiz, 2004.

Pascua Sánchez, María José de la: «Regulación de los afectos y la cultura del amor en la sociedad hispana de la época Moderna», en Iglesias Rodríguez, Juan José; Pérez García, Rafael M.; Fernández Chaves, Manuel Francisco (Coords.): Comercio y cultura en la Edad Moderna. Actas de la XIII Reunión Científica de la Fundación Española de Historia Moderna. Sevilla, 2015.

Pascua Sánchez, María José de la: «Teresa de Jesús, cultura del yo e historia de las mujeres», en Callado Estela, Emilio (Coord.): Viviendo sin vivir en mi: Estudios en torno a Teresa de Jesús en el V Centenario de su nacimiento. Madrid, 2016, pp. 43-72.

Paz Torres, Margarita: «Demonio y mujer: la marca de Satán y el combate contra él», Medievalia: Revista d'Estudis Medievals, 18:2, 2015, pp. 325-353. 
ELENA CARRERA

EL MIEDO INTERSUBJETIVO EN LA AUTOBIOGRAFÍA DE TERESA DE ÁVILA

Pinilla, María José (Ed.): Estampas de la Vida de la Santa Madre Teresa de Jesús grabadas por los famosos artistas Cornelio Galle y Adrián Collaert, impresas en Amberes en 1613. Madrid, 2012.

Pinilla, María José: «Dos «vidas gráficas» de Santa Teresa de Jesús: Amberes 1613 y Roma 1655», Boletín del Seminario de Estudios de Arte y Arqueología. Arte 79, 2013, pp. 183-202.

Pino Díaz, Fermín del (Coord.): Demonio, religión y sociedad entre España y América. Madrid, 2002.

Plamper, Jan: «The History of the Emotions: An Interview with William Reddy, Barbara Rosenwein, and Peter Stearns», History and Theory, 49:2, 2010, 237-265.

Popova, Yanna B.: Stories, Meaning, and Experience: Narrativity and Enaction. Nueva York, 2015.

Portús Pérez, Javier: «Infiernos pintados: iconografía infernal en la Edad Moderna hispánica», en Tausiet, María; Amelang, James S. (Coords.): El Diablo en la Edad Moderna. Madrid, 2004, pp. 253-275.

Pro, Juan: Dossier «Historia de las emociones», en Rubrica contemporanea, 4:7, 2015.

Reddy, William M.: The Navigation of Feeling: A Framework for the History of Emotions. Cambridge, 2001.

Reddy, William M.: The Making of Romantic Love. Chicago, 2012.

Ribera, Francisco de: Vida de la madre Teresa de Jesús [Salamanca, 1590], edición preparada por Jaime Pons. Barcelona, 1908.

Rodríguez-López, Carolina (Coord.): «Historia de las emociones» Cuadernos de Historia Contemporánea, 36, 2014.

Rodríguez-San Pedro Bezares, Luis. E.: «La dualidad de Teresa de Jesús y el proyecto de «Jesuitas Descalzos»», Hispania Sacra, 68, 2016, pp. 299-315.

Roig, Rosendo: «De la visión del infierno a la visión del primer Carmelo (comentario estilístico del capítulo XXXII del «Libro de la vida» de Santa Teresa)», Letras de Deusto, 12:24, 1982, pp. 59-76.

Roldán Viller, Alejandro: «La afectividad en la ascética ignaciana», Manresa, 53, 1981, pp. 33-54.

Roper, Lyndal: Witch Craze: Terror and Fantasy in Baroque Germany. New Haven, 2004.

Rosas Lauro, Claudia (Coord.): El miedo en Perú: siglos XVI al XX. Lima, 2005.

Rosenwein, Barbara H. (Coord.): Anger's Past: The Social Uses of an Emotion in the Middle Ages. Ithaca, 1998.

Rosenwein, Barbara H.: Emotional Communities in the Early Middle Ages. Ithaca, 2006.

Rosenwein, Barbara H.: «Problems and Methods in the History of Emotions», Passions in Context: Journal of the History and Philosophy of the Emotions, 1, 2010, pp. 1-32.

Rovira, Juan: «La meditación del infierno y los ejercicios espirituales de San Ignacio y la Sagrada Escritura», Manresa, 3, 1927, pp. 221-216.

Rowe, Erin Kathleen: «The Spanish Minerva: Imagining Teresa of Avila as Patron Saint in Seventeenth-Century Spain», The Catholic Historical Review, 92:4, 2006, pp. 574-596.

Ediciones Universidad de Salamanca / @®@@ Stud. his., H. ${ }^{a}$ mod., 40, n. 2 (2018), pp. 63-111 
Santa Teresa, Silverio de (Ed.): Procesos de beatificación y canonización de Santa Teresa de Jesús, 3 vols. Burgos, 1935.

Scheer, Monique: «Are Emotions a Kind of Practice (and is That What Makes Them Have a History)? A Bourdieuian Approach to Understanding Emotion», History and Theory, 51:2, 2012, pp. 193-220.

Shields, Stephanie A.: Speaking from the Heart: Gender and the Social Meaning of Emotion. Nueva York, 2000.

Shields, Stephanie A.: «Passionate Men, Emotional Women: Psychology Constructs Gender Difference in the $19^{\text {th }}$ Century», History of Psychology, 10, 2007, pp. 92-110.

Slade, Carole: Teresa of Avila. Author of a Heroic Life, Berkeley, 1995.

Soto, Domingo de: De la justicia y del Derecho [1556]. Madrid, 1968.

Spinks, Jennifer; Zika, Charles (Coords.): Disaster, Death and the Emotions in the Shadow of the Apocalypse, 1400-1700. Basingstoke, 2016.

Sullivan, Erin: Beyond Melancholy: Sadness and Selfhood in Renaissance England. Oxford, 2016.

Tausiet, María; Amelang, James S. (Coords.): Accidentes del alma: las emociones en la Edad Moderna. Madrid, 2009.

Tausiet, María; Amelang, James S. (Coords.): El Diablo en la Edad Moderna. Madrid, 2004.

Teresa de Jesús, Santa: Obras completas, octcva edición, preparada por Efrén De La Madre De Dios y Otger Steggink. Madrid, 1986.

Val Valdivieso, María Isabel del; Gallego Franco, Henar (Coords.): Las huellas de Foucault en la historiografía: poderes, cuerpos y deseos. Barcelona, 2013.

Vázquez de Prada, Valentín: «La reforma teresiana y la España de su tiempo», en Castro Calvo, José María (Coord.): Santa Teresa en el IV centenario de la reforma carmelitana. Barcelona, 1963, pp. 81-96.

Ward Laura; Steeds, Will: Demonios. Visión del diablo en el arte, trad. A. Lino Gonzalvo. Madrid, 2007.

Weber, Alison: Teresa of Avila and the Rhetoric of Femininity. Princeton, 1990.

Weber, Alison: «Saint Teresa, Demonologist», en Cruz, Anne J.; Perry, Mary Elizabeth (Coords.): Culture and Control in Counter-Reformation Spain. Minneapolis, 1992, pp. 171-195.

Weber, Alison: «Spiritual Administration: Gender and Discernment in the Carmelite Reform», Sixteenth Century Journal, 31:1, 2000, pp. 127-150.

Weyer, Johann: De Praestigiis Daemonum et Incantationibus ac Venificiis. Basilea, 1563. 